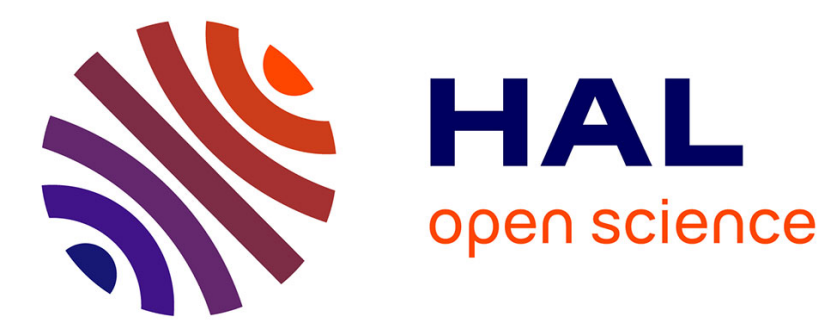

\title{
Intermodality in European metropolises: The current state of the art, and the results of an expert survey covering Berlin, Copenhagen, Hamburg and Paris
} Mirko Goletz, Sonja Haustein, Christina Wolking, Alain L'Hostis

\section{- To cite this version:}

Mirko Goletz, Sonja Haustein, Christina Wolking, Alain L'Hostis. Intermodality in European metropolises: The current state of the art, and the results of an expert survey covering Berlin, Copenhagen, Hamburg and Paris. Transport Policy, 2020, 94, pp.109-122. 10.1016/j.tranpol.2020.04.011 . hal-02569329

\section{HAL Id: hal-02569329 \\ https://hal.science/hal-02569329}

Submitted on 11 May 2020

HAL is a multi-disciplinary open access archive for the deposit and dissemination of scientific research documents, whether they are published or not. The documents may come from teaching and research institutions in France or abroad, or from public or private research centers.
L'archive ouverte pluridisciplinaire HAL, est destinée au dépôt et à la diffusion de documents scientifiques de niveau recherche, publiés ou non, émanant des établissements d'enseignement et de recherche français ou étrangers, des laboratoires publics ou privés. 


\section{Title Page}

\section{Authors}

Mirko Goletz, Sonja Haustein, Christina Wolking, Alain l'Hostis

\section{Title}

Intermodality in European metropolises: The current state of the art, and the results of an expert survey covering Berlin, Copenhagen, Hamburg and Paris

\section{Authors}

Mirko Goletz, DLR Institute of Transport Research, Department of Mobility and Urban Development, Rutherfordstraße 2, 12489 Berlin, Germany, Mirko.goletz@dlr.de

Sonja Haustein, Technical University of Denmark, Department of Technology, Management and Economics , Bygningstorvet, 2800 Kgs. Lyngby, Denmark, sonh@,dtu.dk

Christina Wolking, Technische Universität Berlin, Institute of Land and Sea Transport Systems, Department of Transport Systems, Salzufer 17-19, 10587 Berlin, Germany, christina.wolking@tu-berlin.de

Alain l'Hostis, LVMT, Univ Gustave Eiffel, IFSTTAR, ENPC, F-77447 Marne-la-Vallée, France, alain.lhostis@univ-eiffel.fr

\section{Corresponding Author}

Mirko Goletz, mirko.goletz@dlr.de,+49-30-67055-447

\section{ORCID}

Mirko Goletz, https://orcid.org/0000-0002-6237-1734

Sonja Haustein, https://orcid.org/0000-0001-5219-0115

Christina Wolking, https://orcid.org/0000-0001-7557-9115

Alain l'Hostis, https://orcid.org/0000-0002-2334-4127

\section{Declarations}

\section{Availability of Data and Material}

Two type of data sources where used for this paper: Firstly, travel survey data from Berlin, Hamburg, Copenhagen and Paris. All travel survey datasets that we used require a special permission by their owners and cannot be made publicly available through us. Secondly, we carried out an expert survey amongst which we describe precisely in our paper. We cannot make these data available to the public as we did not ask the experts for their permission on this, and we consider that the new data privacy laws of the EU would not allow us doing so without permission.

\section{Funding}


This research was carried out as part of the Project "Urban Mobility", financed by the Helmholtz Foundation (DE). We furthermore acknowledge financial support from the Danish Ministry of Transport, Building and Housing.

\section{Competing Interests}

Declarations of interest: none

\section{Acknowledgements}

We would like to thank Gaëtan Guillossou for the calculations based on the Danish National Travel Survey and Thomas A. Sick Nielsen for support with the distribution of the Danish Delphi survey. Finally, we express our thanks to all participants in the Delphi survey for their support. 


\begin{abstract}
Intermodality, defined as using more than one mode for a single trip, is frequently discussed as a measure to help achieve more sustainable mobility in Europe, especially in cities. However, intermodality presents challenges for transport providers, and has its drawbacks for users, who prefer connections that do not require changing between transport modes. As a basis for forming recommendations to facilitate intermodality, we first analysed the status quo of intermodal mobility in four European metropolises: Berlin, Copenhagen, Hamburg and Paris. Subsequently, we conducted an expert survey in which we asked experts in the four cities about the future share and development of intermodality, its future relevance and potential of intermodality in transport planning, and how various factors on both the demand and supply side influence the level of intermodal activity. According to our findings, most experts foresee an increase in the share of intermodal trips. They also believe the relevance of including intermodality considerations in transport planning to be increasing. The increase of intermodal mobility will be driven by factors such as reduced vehicle ownership, but also by new mobility patterns. The latter can be explained by social factors such as urbanisation or digitalisation that affect the lifestyle of cities' inhabitants in future.
\end{abstract}

Keywords: urban mobility, intermodality, travel behaviour, transport policies

\title{
Introduction
}

\subsection{Context}

Urban space has become the dominant European geography. As the share of European citizens living in urban areas is expected to grow from $73 \%$ in 2014 to $84 \%$ by 2050 , travel is taking place increasingly in an urban context (United Nations, 2014). Depending strongly as it does on private cars, the current urban mobility system is considered unsustainable; to address this issue, the 2011 White Paper from the European Commission introduced objectives for the future reduction of emissions from transport (European Commission, 2011).

To achieve these goals, it is necessary to consider the current dynamics of urbanisation and mobility. Urbanisation is more and more viewed as a functional phenomenon. Instead of mere continuous built-up areas, cities are defined as agglomeration commuting zones, and city dwellers are characterised by their urban lifestyles (OECD, 2012). Everexpanding cities are leading to the emerging concept of 'city regions' (Dijsktra et al., 2013), a term which encompasses several spatial scales and several transport modes. When cities grow inside their existing boundaries, this leads to more intense mobility, with denser traffic, and longer and larger traffic flows (Eurostat, 2009); cities which expand spatially lead to the need to cover longer distances with a, potentially, smaller numbers of trips.

Public transport (PT) contribution to future urban mobility systems is not expected to decrease significantly. In the context of current urban dynamics, PT is relevant because it can accommodate the growth of mobility. But, as extending heavy transit lines is costly (Vuchic, 2017), rail-based public transport is less relevant when it comes to addressing the increase of the geographic scale of cities. For these reasons, the integration of existing with future urban PT systems 
should play an increasing role in the future, in order to improve user perception of PT, especially for so-called 'intermodal' trip chains, which become more commonplace the larger cities get. Metropolises, defined as large cities, are hence places where intermodality is likely to play a major role. Despite being a concept used for a long time among scholars and practitioners, intermodality is currently receiving a renewed interest due to these global trends (Canzler \& Knie, 2016; Dacko \& Spalteholz, 2014). In this context we focus on the concept of intermodality, defined as using a combination of several transport modes (or at least more than one) for a single trip (Conesa \& L'Hostis, 2013; Gebhardt et al., 2016, L'Hostis et al., 2016), which is regarded as a subset of multimodality (Chlond \& Manz, 2000; Nobis, 2007).

While previous research has demonstrated that multimodality and/or intermodality is related to several demographic and infrastructural factors, such as age, gender, car availability, public transport access or density (see e.g. Buehler \& Hamre, 2015; Heinen \& Chatterjee, 2015; Heinen \& Mattioli, 2019), our study focuses on the role of recent societal changes and mobility trends for intermodality, and the role of transport planning.

\subsection{Factors of intermodality}

To better understand how to support intermodality, we find it important to understand how recent societal and technical developments facilitate or hamper intermodality. We consider three groups of factors as particular relevant:

- $\quad$ societal changes and trends;

- new mobility forms and services; and

- individual motives related to the use of intermodal transport.

Our analysis is inspired by the European research project Mobility4EU, which focuses on societal factors underpinning mobility and logistics (L'Hostis et al., 2016). The societal changes that we consider to be particularly relevant in relation to transport and intermodality are an ageing population, increasing individualism and digitalisation. The ageing population is expected to have huge impacts on the future transport system and travel demand (Coughlin, 2009). While a higher share of the oldest old may lead to a decrease in travel demand, an increasing share of older people remain active and healthy in later life, which may lead to increased travel demand. Le Vine \& Jones (2012) see "a strong inverse relationship between age and change in car mileage" (p. 19): while younger (especially male) people are showing a tendency to lower their annual mileage (Kuhnimhof et al., 2012, 2013) and are less inclined to acquire a driving licence (Delbosc \& Currie, 2013), older drivers (for the most part) want to keep their licence and continue driving as they age still further (Siren \& Haustein, 2013; 2016). Looking well into the future, fully automated cars are expected to further increase older people's car use (Harper et al., 2015; Reimer, 2014). However, 'older people’ refers to a heterogeneous group, which also comprises a segment characterised by multimodal transport use and a less cardependent lifestyle (Haustein \& Siren, 2015). That this multimodal segment is only found in a European context is in line with findings that higher age in Germany is related to higher multimodality, but to higher single-mode usage in the US (Buehler \& Hamre, 2015).

New transport forms such as e-bikes, and car- and ride-sourcing services - all of which broaden the mobility options of older people without necessitating ownership of a car - may work against a future increase in car use, and instead support more multimodal and intermodal travel behaviour. Thus, the way in which the increasing numbers of older 
people will influence the development of intermodality remains uncertain, and will probably depend on the extent to which new services and transport forms take into account the mobility needs and preferences of older people.

As devised in the liquid modern paradigm (Bauman, 2000), current societal evolution is characterised by individualism, by the increasing fluidity of social links (which involve both innovation and precariousness), by the feeling of acceleration of the pace of life, by the rise of social networks, and by the use of information and communication technologies. The increase in individualism can be observed in Europe, where the average number of people living in households (in the EU-15) is forecast to decline from 2.48 in 1995 to 2.17 in 2025 (Laihonen, 2003). This is due to a combination of factors including lower marriage and fertility rates, an ageing population, rapid urbanisation, and rising wealth in emerging markets (Euromonitor, 2013). Car ownership is significantly lower for single households than for multiple-person households (Fornells \& Arrue, 2014), and single parents, those in one-person households and people living apart together relationships are found to use the car less often and/or display more multimodal transport behaviour than is the case with members of more traditional forms of family (Chlond \& Ottmann, 2007; Kuhnimhof et al., 2006; Kunert, 1994; Haustein, 2006). Owing to the smaller household sizes seen today, more complex mobility is needed to establish and maintain social contacts as well as to conduct other activities, and this in turn increases the demand for transport (Brög et al., 2005). In addition, the mobility needs of individuals are increased and made more complex by the liberalisation of working hours and conditions, making commuting patterns less regular (Lanzendorf et al., 2005). All these trends, rather than leading to a straightforward rise in car use, instead favour the adoption of a variety of modes, and hence lead an increase in both multimodality and intermodality.

Finally, digitalisation and technological progress are clearly having a huge impact on the future of transport. Mobility can be considered as digitalised with new expectations by the connected traveller (Goodall et al., 2015), new uses of travel time - which has become an equipped time (Jain \& Lyons, 2008) - and new types of services enabling the digital revolution (L'Hostis et al., 2016). Digitalisation can be regarded as the driving force behind the development of new shared-mobility services such as ride sourcing and ride pooling (see Shaheen (2018) for definitions), and transport planning tools including the concept of mobility as a service (Jittrapirom et al., 2017; Stopka \& Pessier, 2015). While 'mobility as a service' by definition aims to integrate different transport modes (Jittrapirom et al., 2017), and thus facilitates intermodal transport, this is much more uncertain for car-related concepts, such as free-floating car-sharing services or ride sourcing. While research shows that car-sharing users travel more inter- and multimodally than other kinds of road users, (Kopp et al., 2015), it is less certain whether this is the effect of car-sharing membership, or merely a reflection of different user needs and motives pertaining to those who choose to car-share. Recent studies indicate that the effect of car-sharing on car use and ownership is much lower for free-floating concepts than traditional car-sharing (Becker et al., 2017; 2019) and that earlier studies generally may have overestimated the effect of car-sharing (Jain et al., 2020; Mishra et al., 2015; 2019).

The way in which people evaluate different transport modes in terms of functional and symbolic-affective motives is found related to their mode choice (Anable \& Gatersleben, 2005; Hunecke et al., 2007; Steg, 2005). It is thus expected that people who appreciate the comfort, status and privacy of the car are more difficult to motivate to use sharedmobility solutions, PT and combinations of both. By contrast, environmental awareness and the wish for social contact may motivate intermodal transport solutions, and new mobility trends might evolve out of the evolving thinking of transport users (Goletz et al., 2016). 
To get a clearer picture of how various societal trends, emerging transport services and user motives facilitate - or hamper - intermodal transport, we conducted a Delphi survey (see Dalkey, 1969); the Delphi technique is also described in Section 2) among mobility experts in four European cities. The selected cities represent urban mobility cultures (Klinger et al., 2013), which differ in terms of the importance in their transport culture of public transport, the car and cycling, and in the current status of intermodality in them. We expect 'transit metropolises' - in which PT is of high quality, well adapted to the urban environment, and widely used - to already be showing high levels of intermodality for the combination of different PT modes, while potential is also seen in the combination of PT with car and bike-sharing services. By contrast, we expect that 'cycling cities' will see more potential in PT-related services, and that car-oriented cities will see higher potential in all directions. The results may thus allow for conclusions to be drawn with regard to the different and distinct urban mobility cultures, but may also point to similarities across those cultures, with specific local differences.

\subsection{The present study}

This paper aims to identify the key factors involved in intermodality using two data sources: travel survey data on intermodality and a Delphi survey. We made use of these two data sources to find out more about the actual statistical indicators that describe intermodal travel behaviour, as such information have rarely been published before, especially not in a comparative way. With the Delphi survey, we then addressed the question of how urban intermodality will develop in the future and which role transport planning can or should have in this process.

Using travel survey data, this paper first describes (in Section 3.1) the current level of intermodality in the four European case study cities that were selected, on the basis of criteria related to the generalisation of the results to other European cities, data availability, and the potential for intermodality (see Section 2.1). Using the results of a Delphi survey among experts in these case study cities, this paper assesses:

- the future development of intermodality with regard to modal split and usage patterns;

- the future relevance and potential of intermodality for transport planning; and

- the factors (on both the supply and the demand side) influencing intermodal usage.

On the basis of these findings, we draw conclusions about the role that intermodality can and will play in the future, and how it can be applied so as to contribute to the goals of transport planning in urban areas.

\section{Methodology}

This section explains the methodological approach of our study. It describes how we selected the reference cities (see Section 2.1), analysed travel survey data (see Section 2.2), and designed the Delphi survey (which entails also how we recruited the participants, see Section 2.3).

\subsection{Selection of case study cities (Berlin, Hamburg, Copenhagen, Paris)}

Our study used four European cities as case studies. Case studies are used in social sciences as practical examples for analysing selected questions. According to Gerring (2004), a case study is an "intensive study of a single unit for the purpose of understanding a larger class of (similar) units" that is "observed at a single point in time or over some 
delimited period of time." (p. 342). Flyvbjerg (2006) confirms that cases are suitable for generalisation, and that this generalisability increases if selection follows an appropriate strategy. Thus, the selection of cases can and should be guided by sensible criteria and by using strategies for selection. (Flyvbjerg, 2006) defines various approaches towards case study selection, differentiating broadly between random- and information-oriented selection of cases. Random selection can be used to avoid systematic bias in a sample, whereas an information-oriented selection approach aims to maximise the utility of information obtained from the samples.

As our study explores the general role of intermodality in transport, and we aim to derive findings that can be applied to other cities, we followed an information-oriented selection process based on criteria. Our goal was to maximise the utility of information we could gain from our cases, regarding the role and potential of intermodal travel in European urban areas. The criteria we defined for our set of cities were:

- adequate differentiation with respect to population and area - to cover different types of cities in Europe to enable some generalisation regarding similarly set-out cities;

- some variation among the study cities in their existing modal split ${ }^{1}$ - again, for generalisation;

- visible development towards, and potential for, intermodal travel behaviour in terms of policies, mode availability and usage patterns - to enable an understanding of how and why intermodal travel evolves, including the policies behind it; and

- availability of and access to recent travel data - to be able to derive an overview of the cities' mobility patterns.

The selection was partially predetermined owing to the connection between this study and the Urban Mobility project (as described in Gebhardt et al., 2016), in which intermodality in the two German cities of Berlin and Hamburg is being analysed. Hence, we had to choose further cities which complemented these two cities. We evaluated various European cities using the criteria above (see Table 1), and finally decided on Paris and Copenhagen to complement the original two (see Figure 1).

\begin{tabular}{|l|l|l|}
\hline \multicolumn{2}{|c|}{ Table 1 Preselection of cities } \\
\hline Type & Candidates & $\begin{array}{l}\text { Representative of (paradigmatic } \\
\text { for) }\end{array}$ \\
\hline European megacities & $\begin{array}{l}\text { Paris, Vienna, Madrid, London, } \\
\text { Istanbul, Berlin }\end{array}$ & $\begin{array}{l}\text { European capitals of high density } \\
\text { with a large variety of different } \\
\text { modes }\end{array}$ \\
\hline Regional cutting-edge cities & $\begin{array}{l}\text { Lyon, Copenhagen, Amsterdam, } \\
\text { Hamburg }\end{array}$ & $\begin{array}{l}\text { European cities of population } \\
<1 \text { million with forward-looking } \\
\text { transport policies }\end{array}$ \\
\hline
\end{tabular}

$1 \quad$ Mode share in European cities is characterised by a very significant diversity. To illustrate the point, the share of the bicycle in European cities ranges between zero and over 40\%, as can be observed from the EPOMM (European Platform on Mobility Management) database (EPOMM, n.d.). 


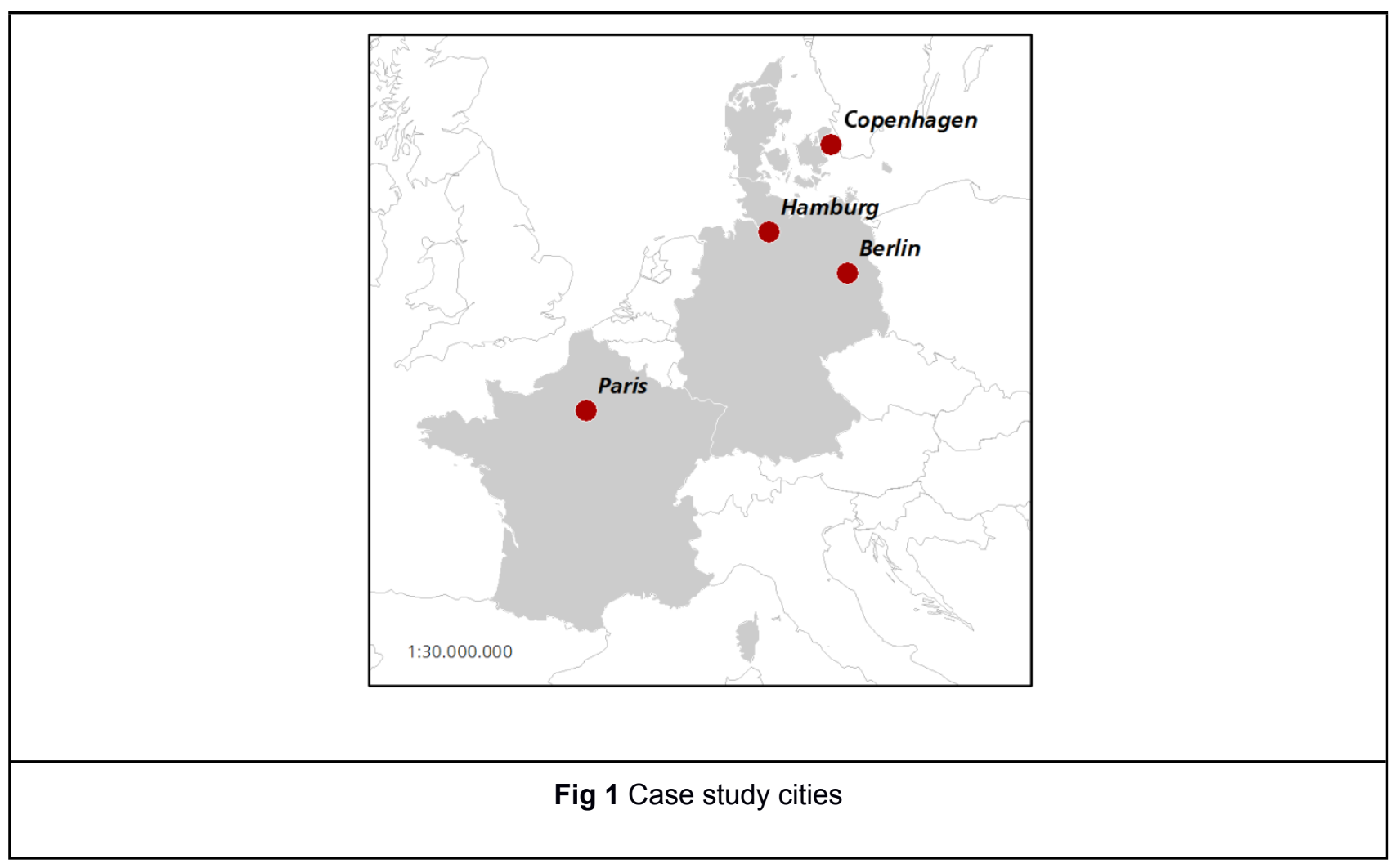

\subsection{Travel survey analysis}

The quantitative analysis in the four case study cities is based on travel surveys. We used the datasets shown in Table 2 . For Berlin and Hamburg, the approach is described in more detail in a 2016 journal article (Gebhardt et al., 2016), and the same approach was also applied in Paris and Copenhagen. For Copenhagen, we used data from the Danish National Travel Survey 2015 (Christiansen \& Warnecke, 2018). In Paris, the Enquête Globale Transport (EGT) (STIF/DRIEA, 2010) was used. 


\begin{tabular}{|c|c|c|c|c|}
\hline City & Berlin & Hamburg & Copenhagen & Paris \\
\hline Population & 3.4 million $(2013)$ & 1.8 million $(2008)$ & $\begin{array}{l}\text { Copenhagen: } \\
0.6 \text { million (2015) } \\
\text { Agglomeration: } 1.3 \\
\text { million (2016) } \\
\end{array}$ & $\begin{array}{l}\text { Paris: } \\
2.2 \text { million }(2010) \\
\text { Agglomeration: } \\
12.2 \text { million }(2010) \\
\end{array}$ \\
\hline Dataset & $\begin{array}{l}\text { Mobility in Cities (SrV) } \\
(\mathrm{SrV}, 2013)\end{array}$ & $\begin{array}{l}\text { Mobility in Germany } \\
\text { (MiD) (+ regional } \\
\text { extension) (MiD, 2008) }\end{array}$ & $\begin{array}{l}\text { Danish National Travel } \\
\text { Survey (DNTS) } \\
\text { (Christiansen \& } \\
\text { Warnecke (2018)) } \\
\end{array}$ & $\begin{array}{l}\text { Enquête Globale } \\
\text { Transport (EGT) } \\
\text { (STIF/DRIEA, 2010) }\end{array}$ \\
\hline Year & $2008 / 2013^{2}$ & 2008 & 2015 & 2010 \\
\hline Sample size & $\begin{array}{l}41050 \text { persons } \\
19354 \text { households } \\
104139 \text { trips } \\
\end{array}$ & $\begin{array}{l}3200 \text { persons } \\
1575 \text { households } \\
16177 \text { trips } \\
\end{array}$ & $\begin{array}{l}1083 \text { persons } \\
3569 \text { trips } \\
\end{array}$ & $\begin{array}{l}43000 \text { persons } \\
18000 \text { households } \\
143000 \text { trips } \\
\end{array}$ \\
\hline Survey days & $\begin{array}{l}\text { Tuesday-Thursday, no } \\
\text { holidays }\end{array}$ & Monday-Friday & Monday-Friday & $\begin{array}{l}\text { Monday-Sunday (15000 } \\
\text { households Mo-Fr; } 1500 \\
\text { households Sat \& Sun } \\
\text { each day) }\end{array}$ \\
\hline $\begin{array}{l}\text { Intermodal } \\
\text { combinations }\end{array}$ & \multicolumn{2}{|c|}{$\begin{array}{ll}\text { - } & \text { Bike }-\mathrm{PT}^{*}(\mathrm{~S}-/ \mathrm{U}-\mathrm{Bahn}, \text { tram, bus }) \\
\text { - } & \mathrm{Car}-\mathrm{PT} \\
\text { - } & \mathrm{PT}-\mathrm{PT} \\
& \text { Other vehicle combinations }\end{array}$} & $\begin{array}{ll}\text { - } & \text { PT (train/bus) - } \\
& \text { bike } \\
\text { - } & \text { PT - car } \\
\text { - } & \text { Train - bus }\end{array}$ & $\begin{array}{l}\text { - } \text { Bike-PT (bus, } \\
\text { métro, tramway, } \\
\text { rail) } \\
\text { - } \quad \text { Car-PT } \\
\text { - } \\
\text { 2-wheel-PT } \\
\text { PT - PT }\end{array}$ \\
\hline
\end{tabular}

The travel surveys were analysed with respect to intermodality, following the definition of intermodality provided by (Jones et al., 2000) and (Chlond, 2013), wherein intermodal trips are trips comprising more than one mode of transport on a single trip, with walking excluded. This, for example, means that the combination of bicycle and metro is seen as an intermodal trip, just as the combination of different modes of PT, such as tram and metro. However in the course of one trip, neither combining walking and metro, nor using different metro lines (metro-metro) is considered intermodal (Gebhardt et al., 2016).

Owing to different survey approaches, the results are not perfectly comparable: for example, the survey days during the week differ, and some surveys classify the PT modes into rail-based and road-based modes. Table 2 lists the combinations of intermodal trips that can be picked out using the survey data, providing an overview of the intermodal combinations we included.

\subsection{Expert survey}

Data extracted from the travel surveys provide first insights into current levels of intermodality in the case study cities. To obtain information on the potential of intermodality for promoting sustainable transport, its future relevance, and the factors influencing it, we conducted a two-wave survey with experts from our four case study cities. Our survey approach was designed in two-waves (inspired by the Delphi technique). The approach is described in the next section.

\subsubsection{Survey method selection}

Our survey methodology was designed to be carried out in two waves, as we intended to discuss findings of the first wave in the group of participants. We therefore leaned towards the Delphi survey method (Dalkey, 1969; Hasson et al., 2000) which according to (Linstone \& Turoff, 1975, p. 3) “[...] may be characterized as a method for structuring a

2 Aggregate data, enabling a comparison of mono- and intermodal trips, were available for SrV 2013; all other data came from SrV 2008. 
group communication process so that the process is effective in allowing a group of individuals, as a whole, to deal with a complex problem." Besides this, Linstone and Turoff name "exploring urban and regional planning options" as an area of applicability for the Delphi technique. Since literature provides only limited guidance on how to adequately apply the method, researchers frequently use a flexible approach, which is modified according to the research purpose. A wide range of different approaches to the Delphi method thus exists. This flexibility is often criticised though, as it can diminish methodical precision (Hasson et al., 2000).

However, there are certain characteristics that can be considered essential while applying the Delphi technique. It is centred on a survey, which has to be conducted in at least two rounds (or waves). In case of deviating answers, summarised feedback is given in subsequent rounds and the experts - also called panellists - have the opportunity to include these findings when answering the questions posed in the next wave (Hasson et al., 2000; Häder, 2014). The aim of this method is to reduce the range of opinions, and to reach consensus or dissent, and ultimately to create forecasts and statements which take into account the knowledge of the experts (Häder, 2014). Further characteristics of this iterative method are anonymity of the experts and the opportunity to identify a statistical group response. The panellists never have to meet, which has two positive effects: first, the time taken and costs incurred by the survey are reduced, and second, the panellists do not directly influence each other in forming their responses (Linstone \& Turoff, 1975; Habibi et al., 2014).

The Delphi approach hence possesses characteristics suited to our research purposes, because it allows us to structure and compare the opinions about intermodality of experts in the subject who come from different European cities. We expect the results to allow the identification of success factors relating to intermodality that tend towards its promotion.

\subsubsection{Panel recruitment}

Appropriate recruitment of the panel is essential for expert surveys, and a significant determining factor in a study's validity. Whether someone can be considered an expert depends on that person's knowledge and competence in the relevant field (Linstone \& Turoff, 1975). Following the recommendations of Vorgrimler and Wübben (2003), the panellists had to fulfil the following requirements:

- experience and expertise in the sector of mobility and transport;

- an overview knowledge of related disciplines such as urban development and transport policy;

- availability and the willingness to communicate; and

- residence within, and knowledge of, one of our four case study cities.

To assure that the panellists fulfil the above mentioned criteria, we directly identified suitable experts, mainly using contacts from professional networks. In each city we intended to cover the relevant stakeholders from the field of urban mobility, and contacted experts from science/ academia, public transport companies / authorities and the public sector, following the triple helix approach (Etzkowitz \& Leydersdorff, 1995). To furthermore ensure that we had identified the right experts, a set of questions was included as subjective competency assessment. The panellists assessed their knowledge about the fields: mobility and transport, urban development, intermodality/ multimodality and transport policy in five steps, ranging from very experienced to no experience at all. 
We dropped incomplete responses and respondents who did not assess themselves to be very experienced or experienced in at least one of the four knowledge fields. Overall, we achieved a share of experts who answered being very experienced or experienced that ranges between $74 \%$ and $100 \%$ per competency field (Table 3 ).

\begin{tabular}{|c|c|c|c|c|}
\hline Case study city & $\begin{array}{l}\text { Mobility and } \\
\text { transport }\end{array}$ & Urban development & $\begin{array}{l}\text { Intermodality and } \\
\text { multimodality }\end{array}$ & Transport policy \\
\hline Berlin (n=17) & $17 / 17(100 \%)$ & $14 / 17(82 \%)$ & $17 / 17(100 \%)$ & $14 / 17(82 \%)$ \\
\hline Hamburg ( $n=13$ ) & $13 / 13(100 \%)$ & $13 / 13(100 \%)$ & $11 / 13(85 \%)$ & $11 / 13(85 \%)$ \\
\hline Copenhagen $(n=23)$ & $23 / 23(100 \%)$ & $17 / 23(74 \%)$ & $17 / 23(74 \%)$ & $19 / 23(83 \%)$ \\
\hline Paris (n=14) & $14 / 14(100 \%)$ & $10 / 14(71 \%)$ & $11 / 14(79 \%)$ & $12 / 14(86 \%)$ \\
\hline
\end{tabular}

Experts were invited to participate in the survey via e-mail. We sent a reminder in each Delphi-round after two weeks and closed the pool two weeks thereafter. Table 4 shows the number of experts recruited and the response rates. We achieved a response rate of $74 \%$ in round 1 , and $58 \%$ in round 2 . According to Häder (2014) a response rate of approximately $30 \%$ is common in the first round, and a response rate of 70 to $75 \%$ in the second. For Paris and Copenhagen, response rates of the first round are missing as we addressed some experts through a mailing list and hence do not know precisely how many experts finally received the survey link. In the second round, participants were contacted directly by the survey administrator, which was in case of the German cities the same persons as in round 1, while this was not the case in Paris and Copenhagen, which may explain the comparably low response rates. On average, survey rates in round 1 are thus higher than expected, while they were lower than expected in round 2 . The first round was conducted in January and February in 2017, the second round between April and June 2017.

\begin{tabular}{|l|l|l|l|l|}
\hline \multicolumn{4}{|l|}{ Table 4 Panel recruitment } \\
\hline Case study city & Survey round 1 & Response rate 1 & Survey round 2 \\
\hline Berlin & $\mathrm{N}=17$ & $47 \%(17 / 36)$ & $\mathrm{N}=13$ & Response rate 2 \\
\hline Hamburg & $\mathrm{N}=13$ & $100 \%(13 / 13)$ & $\mathrm{N}=11$ & $77 \%(13 / 17)$ \\
\hline Copenhagen & $\mathrm{N}=23$ & unknown & $\mathrm{N}=8$ & $85 \%(11 / 13)$ \\
\hline Paris & $\mathrm{N}=14$ & unknown & $\mathrm{N}=9$ & $35 \%(8 / 23)$ \\
\hline Total & $\mathrm{N}=67$ & $74 \%$ & $\mathrm{~N}=41$ & $56 \%(9 / 14)$ \\
\hline
\end{tabular}

The participants' fields of employment are shown in Figure 2 (for the respondents of round 1). Panellists in Copenhagen work predominantly in the public sector, while those from Hamburg are fairly evenly split between PT companies, the public sector and research. In Berlin, people working in companies (all companies which are related to the transport sector, such as the BVG (the main public transport company of Berlin), Deutsche Bahn AG (Germany's national railway carrier) and VBB (the transport association responsible for planning public transport in Berlin and the surrounding state of Brandenburg)) are most strongly represented, while the great majority of panellists in Paris are researchers. We tried balancing the field of employment of panellists in round 1 in Paris by contacting more people from public sector and public transport companies at the time we sent out the reminder, but the response rate from other sectors then academia remained quite low. When interpreting the results presented in this paper, it should be borne in mind that responses might be influenced by the field of employment of the panellists.

3 For Copenhagen and Paris, the response rate in round 1 is unknown, as participants were contacted using a mailing list comprising a homogenous group of people, but with an unknown number of recipients. 


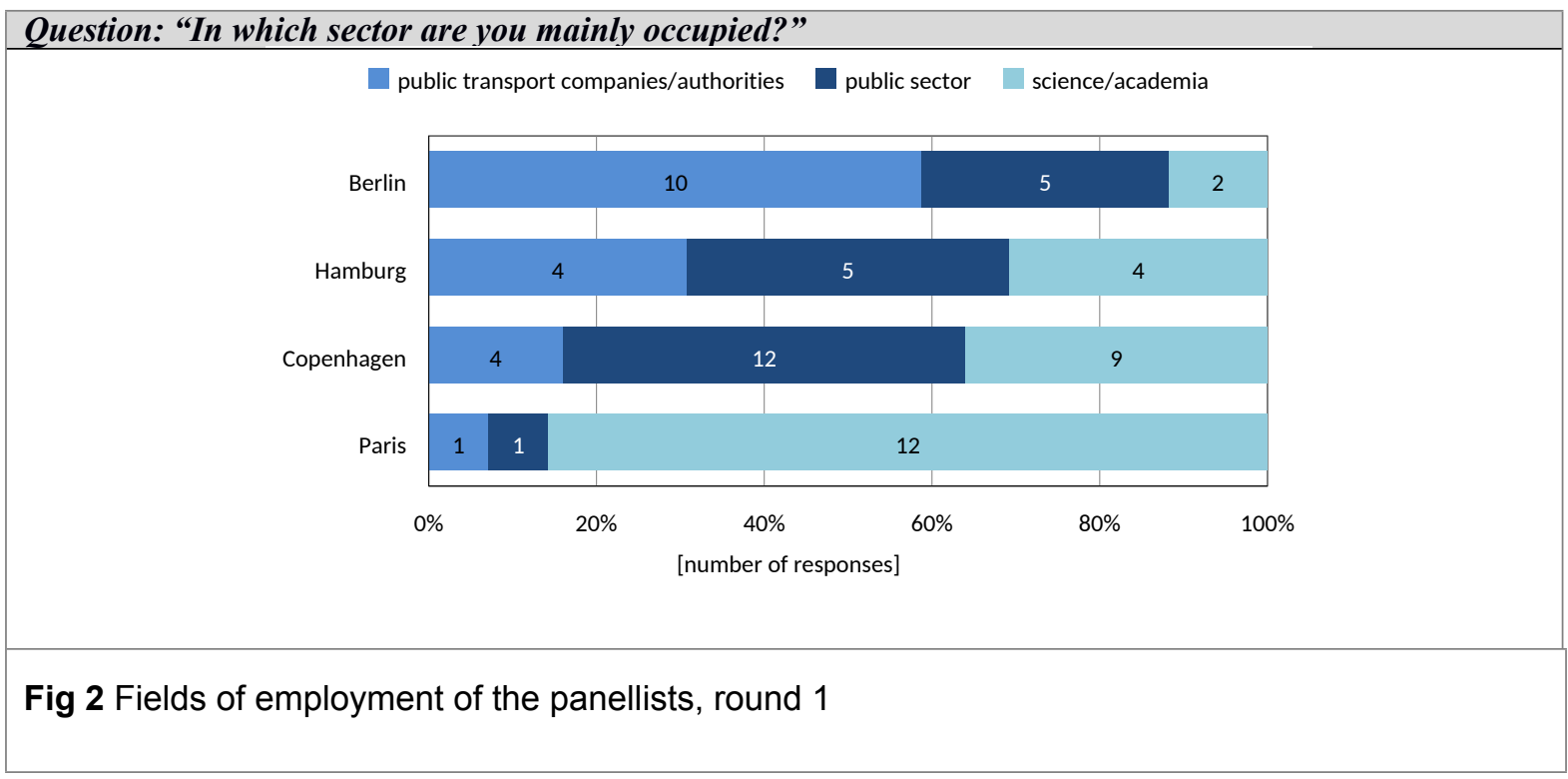

\subsubsection{Survey outline}

In the first round, our main aim was to gain insights into general aspects of intermodality, such as its expected future development and its relevance to transport planning in each city. Furthermore, we focused on influencing factors, in both the demand and supply sides. The factors to be included in the survey (mobility concepts and services, potentially relevant user motives) were selected on the basis of the results of an expert workshop held with transport researchers in January 2017, in which participants had to rank factors that had previously been selected on the basis of a literature review. The questions in the second round were built upon the results of the first round. Whereas we originally planned to assess some of the questions of the first round again in order to reach consensus among experts, the results of the survey were in fact fairly homogeneous; we therefore considered it more relevant to provide selected results as feedback and to include further questions. Since user perceptions of intermodality had been identified as important in the first round, our goal was to assess them in more detail in the second. The second round also dealt with the effects of an improved intermodality and focused on future developments in urban mobility as well as on new mobility concepts and their interactions with intermodality. Table 5 shows the questions, together with the options for the answers, and in which survey wave they were asked.

\begin{tabular}{|l|l|l|l|}
\hline \multicolumn{2}{|l|}{ Table 5 Overview of the questionnaire } & Survey wave \\
\hline $\begin{array}{l}\text { Questions } \\
\text { Questions were transformed into sentences in English (for } \\
\text { Copenhagen), German (for Berlin and Hamburg) and } \\
\text { French (for Paris). }\end{array}$ & Answer/format categories & 1 \\
\hline Future development of intermodality & 2 \\
\hline$\bullet \quad$ Future relevance of intermodality (its share in 2030) & Slider from 0-100\% & 2 \\
\hline $\begin{array}{l}\text { Replacement of single-mode trips by intermodal trips } \\
\text { in 2030 (probability) }\end{array}$ & $\begin{array}{l}\text { 5-point scale } \\
(1=\text { very unlikely; 5 = very likely) }\end{array}$ & 2 \\
\hline $\begin{array}{l}\text { Future development of intermodal combinations } \\
\text { (probability) }\end{array}$ & $\begin{array}{l}5 \text {-point scale } \\
(1=\text { very unlikely; 5 = very likely) } \\
\text { (probability) }\end{array} \quad \begin{array}{l}\text { Including new forms of mobility in intermodal trips } \\
\text { (1= very unlikely; 5 = very likely) }\end{array}$ & Open question: up to three possible answers & 1 \\
\hline
\end{tabular}




\begin{tabular}{|c|c|c|}
\hline (which forms of mobility) & & \\
\hline \multicolumn{3}{|l|}{ Future relevance and potential for transport planning } \\
\hline $\begin{array}{l}\text { - Future relevance of intermodality in transport planning } \\
\text { (relevance as an approach to a more sustainable transport } \\
\text { policy) }\end{array}$ & $\begin{array}{l}\text { 5-point scale } \\
(1=\text { irrelevant; } 5=\text { very relevant })\end{array}$ & 1 \\
\hline $\begin{array}{l}\text { - Potential to contribute to objectives of sustainable } \\
\text { transport planning, part a (promotion of 'green' modes) } \\
\text { and part b (promotion of a more attractive cityscape) } \\
\text { (probability) }\end{array}$ & $\begin{array}{l}\text { 5-point scale } \\
(1=\text { very unlikely; } 5=\text { very likely })\end{array}$ & 2 \\
\hline \multicolumn{3}{|l|}{ Influencing factors } \\
\hline $\begin{array}{l}\text { - Influencing factors on the demand side (social influencing } \\
\text { factors) }\end{array}$ & $\begin{array}{l}\text { 3-point scale } \\
(1=\text { limiting; } 2=\text { neutral; } 3=\text { promoting or } \\
\text { enabling })\end{array}$ & 1 \\
\hline - $\quad$ Influencing factors on the supply side (mobility services) & $\begin{array}{l}\text { 3-point scale } \\
(1=\text { limiting; } 2=\text { neutral; } 3=\text { promoting or } \\
\text { enabling })\end{array}$ & 1 \\
\hline $\begin{array}{l}\text { Individual user motives and motivation (role of motives, } \\
\text { when a user decides to travel intermodally) }\end{array}$ & $\begin{array}{l}\text { 5-point scale } \\
(1=\text { does not matter; } 5=\text { very big role })\end{array}$ & 2 \\
\hline $\begin{array}{l}\text { - Individual user motives and motivation (that discourage } \\
\text { intermodal travelling) }\end{array}$ & $\begin{array}{l}\text { 5-point scale } \\
(1=\text { does not discourage } ; 5=\text { strongly } \\
\text { discourages })\end{array}$ & 2 \\
\hline \multicolumn{3}{|l|}{ Personal information } \\
\hline - $\quad$ Field of employment & $\begin{array}{l}\text { Categories: } \\
\text { Economy; municipal administration; } \\
\text { research/science; transport associations; others }\end{array}$ & 1 \\
\hline - $\quad$ Self-assessment & $\begin{array}{l}\text { 5-point scale } \\
(1=\text { not experienced ; } 5=\text { very experienced }) \\
\text { Categories: mobility and transport; urban } \\
\text { development; intermodality } / \text { multimodality; } \\
\text { transport policy }\end{array}$ & 1 \\
\hline
\end{tabular}

\section{Results}

This section first compares the results of the travel survey analysis in the case study cities (Section 3.1) and then presents the survey results (Section 3.2).

\subsection{Intermodality in the case study cities - travel survey analysis}

Figure 3 shows the existing (or recent) modal split in the case study cities. With about 40\%, Hamburg and Paris have the highest percentage of car trips, and equally high shares of non-motorised modes, while the remaining $20 \%$ of trips are made by PT. These two cities differ from each other mainly in the role that cycling and walking play. Compared to these rather car-oriented so-called transit metropolises, Berlin can be described as a true transit metropolis, since the shares of trips made by PT, walking and the car are almost equal, at around 30\%. The bicycle plays a similar role as it does in Hamburg. By contrast, Copenhagen is a 'cycling city', as almost one third of trips in it are made by bike. The percentage of car trips is similar to that seen in Berlin, while PT trips are at a similar level to those made in Hamburg and Paris. 


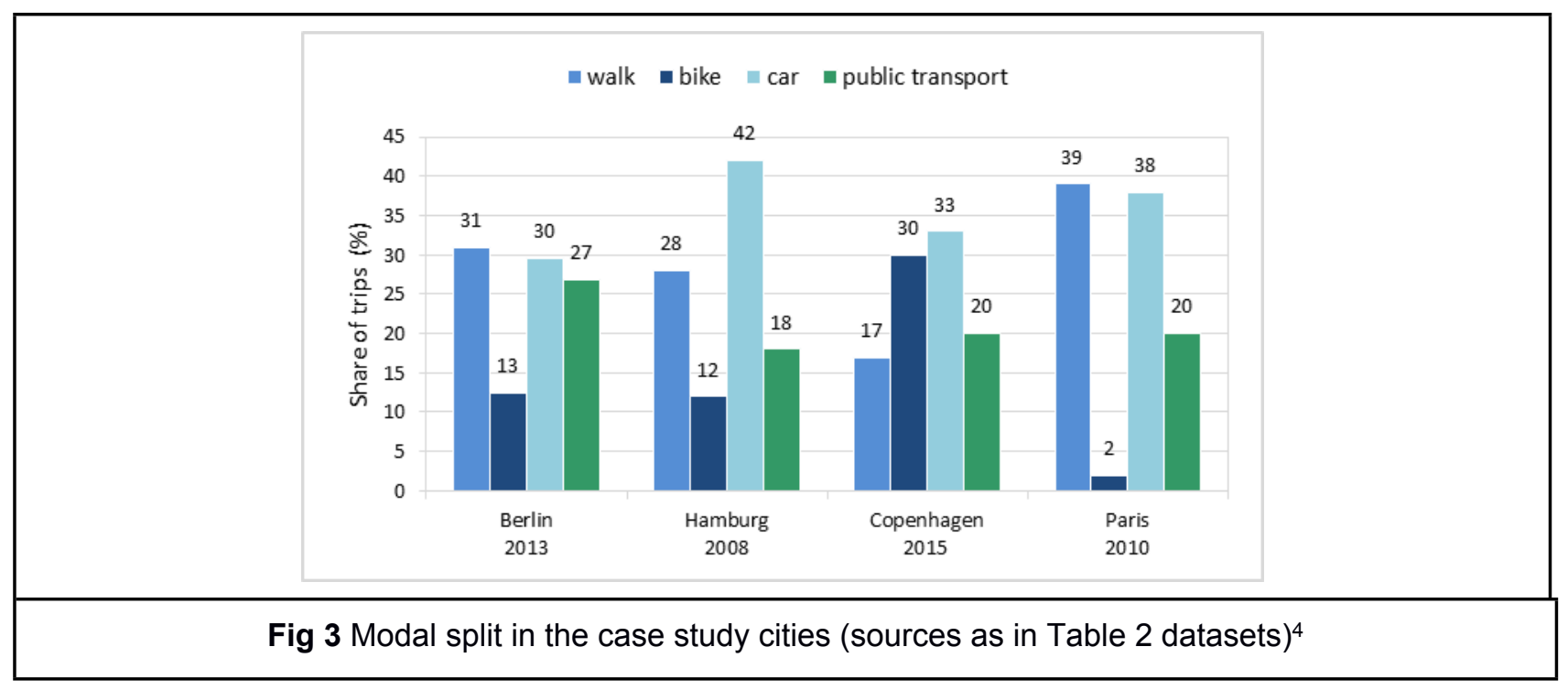

Figure 4 shows the share of single-mode trips in relation to intermodal trips in our case study cities. In all cities more than $90 \%$ of trips were single-mode. The highest percentage of intermodal trips is found in Berlin, the lowest in Copenhagen. It should be noted that the figures can show up any tendencies towards intermodality in a given city, but one city's figures cannot be compared with those of another - other than in the broadest terms - as surveying techniques vary.

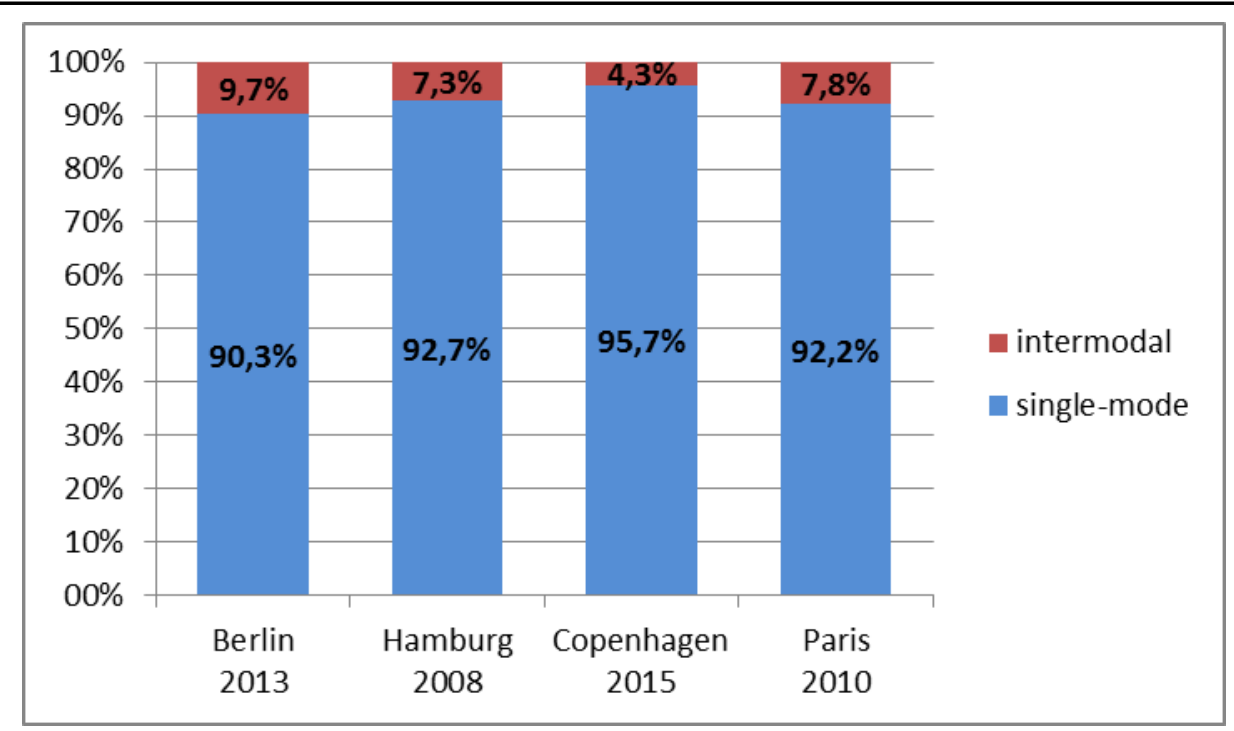

Fig 4 Share of intermodal and single-mode trips in the case study cities (sources as in Table 2 datasets)

\section{Combining different modes of transport}

A closer look at intermodal trips reveals that the combination of different modes of transport varies between the cities (see Figure 5). However, the combination of $P T$ and $P T$ can be identified as the most prevalent throughout all the cities.

$4 \quad$ Where percentages do not sum to $100 \%$, this is due to rounding. 
Whereas this combination is by far the most frequently used in Berlin, Hamburg and Paris, the citizens of Copenhagen use the combination bicycle and public transport just as often. Taking one's bike on-board in the S-train in and around Copenhagen is free of charge, and supported by dedicated bicycle carriages. The low percentage of intermodal trips in Copenhagen can also be explained by its high share of cycling trips, as many destinations can be reached by bike without needing to switch to other modes.

Of particular note is also the slightly higher share of intermodal trips using car and public transport in Paris (1.4\%) and Hamburg (1.0\%) than in Berlin (0.6\%) and Copenhagen (0.5\%). In Paris, the combination of bicycle and public transport is of no relevance $(0.1 \%)$, which is not surprising given the low level of cycling in the city.

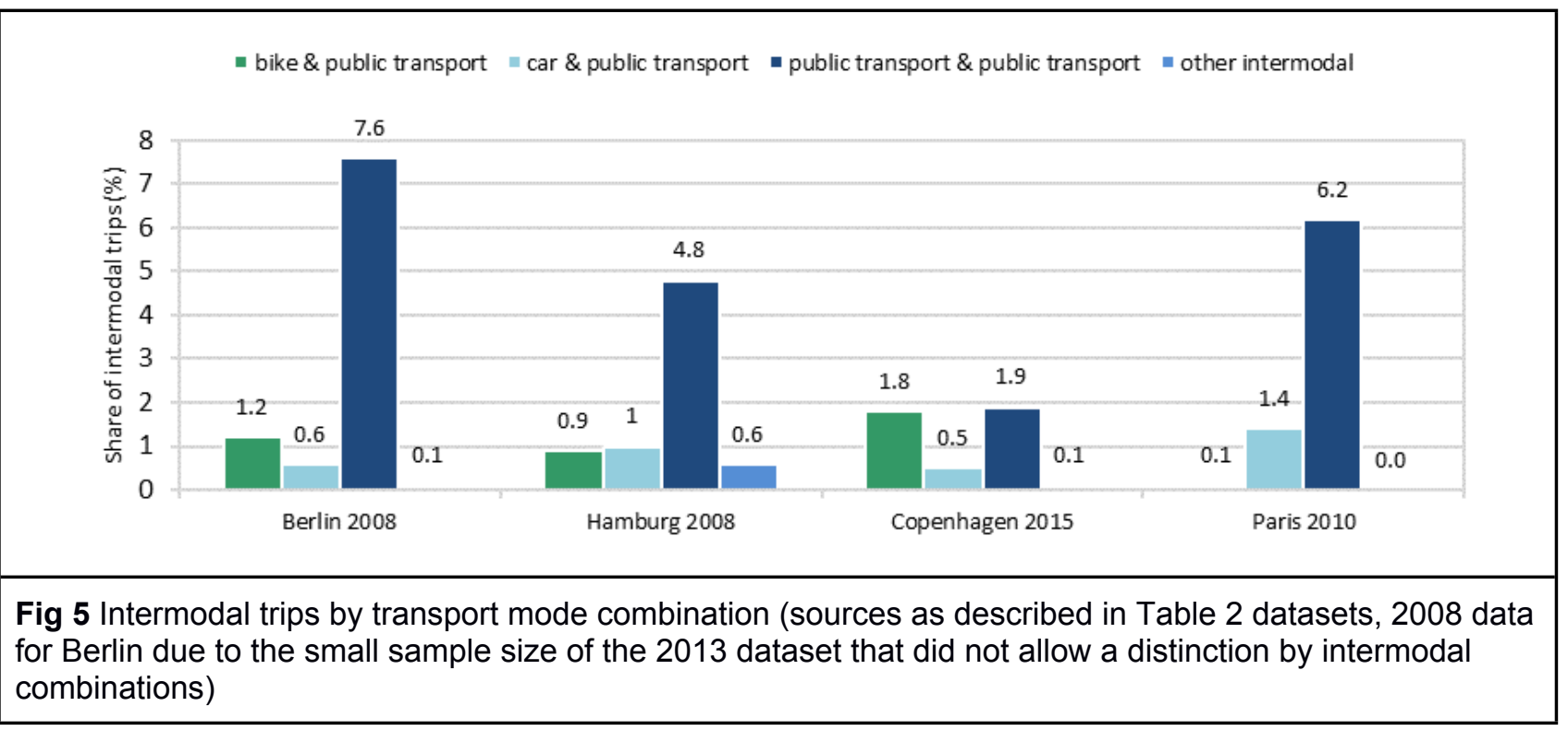

\subsection{Findings of the expert survey}

This section shows the results of both survey rounds.

\subsubsection{Future development of intermodality}

First of all, considering the existing levels of intermodal practices, we focus on how the future of intermodality is considered for each city. Is intermodality seen as a strategic issue? What is its role in a strategic transport planning perspective?

Faced with the current share of intermodal trips in the case study cities, the experts were asked to estimate the likely future share of intermodal trips for their city in 2030. Table 6 shows the results. Taking the mean values, the highest shares are expected in Berlin (27.1\%) and Paris (26.7\%). Lower values are projected in Hamburg (22.2\%) and Copenhagen (18.9\%). Taking into account the initial share of intermodal trips, all experts anticipate an increase of between 14 and 19 percentage points.

Table 6 Future share of intermodal trips, round 1

Question: "Please indicate what, in your opinion, the share of intermodal journeys in Berlin/Hamburg/Copenhagen/Paris will look like in 2030.“ 


\begin{tabular}{|l|l|l|l|l|l|}
\hline City & $\begin{array}{l}\text { Initial share of } \\
\text { intermodal trips }\end{array}$ & $\begin{array}{l}\text { Mean value of the } \\
\text { experts' estimation }\end{array}$ & Median & $\begin{array}{l}\text { Standard } \\
\text { deviation }\end{array}$ & $\begin{array}{l}\text { Estimated increase in } \\
\text { percentage points }\end{array}$ \\
\hline Berlin & $9.7 \%$ & $27.1 \%$ & $\mathbf{2 0}$ & $\mathbf{2 1 , 3}$ & $\mathbf{1 7 . 4 \%}$ \\
& $(2013)$ & $(2030)$ & $22.2 \%$ & & \\
\hline Hamburg & $7.3 \%$ & $(2030)$ & $\mathbf{2 2 , 3}$ & $\mathbf{1 4 . 9 \%}$ \\
& $(2008)$ & $19.3 \%$ & $\mathbf{1 5}$ & $\mathbf{1 9 , 4}$ & $\mathbf{1 5 \%}$ \\
\hline Copenhagen & $4.3 \%$ & $(2030)$ & $\mathbf{1 5}$ & $\mathbf{2 4 , 5}$ & $\mathbf{1 8 . 9 \%}$ \\
\hline Paris & $(2015)$ & $26.7 \%$ & $(2030)$ & & \\
\hline
\end{tabular}

Since motorised individual transport comes with a number of negative side effects, one of the major goals in sustainable transport planning is to reduce the number of trips made by car. We addressed this question by asking the experts from which single modes they expect users to switch to intermodal journeys. Figure 6 depicts the results. For clearer presentation, the responses (on the five-point scale of likelihood: see Table 5) were aggregated from five categories to create two categories. Values one and two were reduced to one category ('likely'), as were four and five ('unlikely'), the neutral value ('neither') being excluded from the diagram. Accordingly, the results can be shown in so called 'iceberg diagrams', which emphasise the outcome, and show whether experts agree or disagree on any given aspect (Häder \& Häder, 2014). We will use such iceberg diagrams throughout this paper for this type of question.

Most experts consider a shift from single-mode car trips as highly likely; only few experts consider it unlikely.

Regarding PT, the same tendency can be found in Berlin and Paris, where most experts think that today's trips with only one means of PT will need to be combined as two PT modes. The aggregated results of all cities show that the panellists, for the most part, expect both single-mode trips by car and single-mode trips by PT to be replaced by intermodal trips.

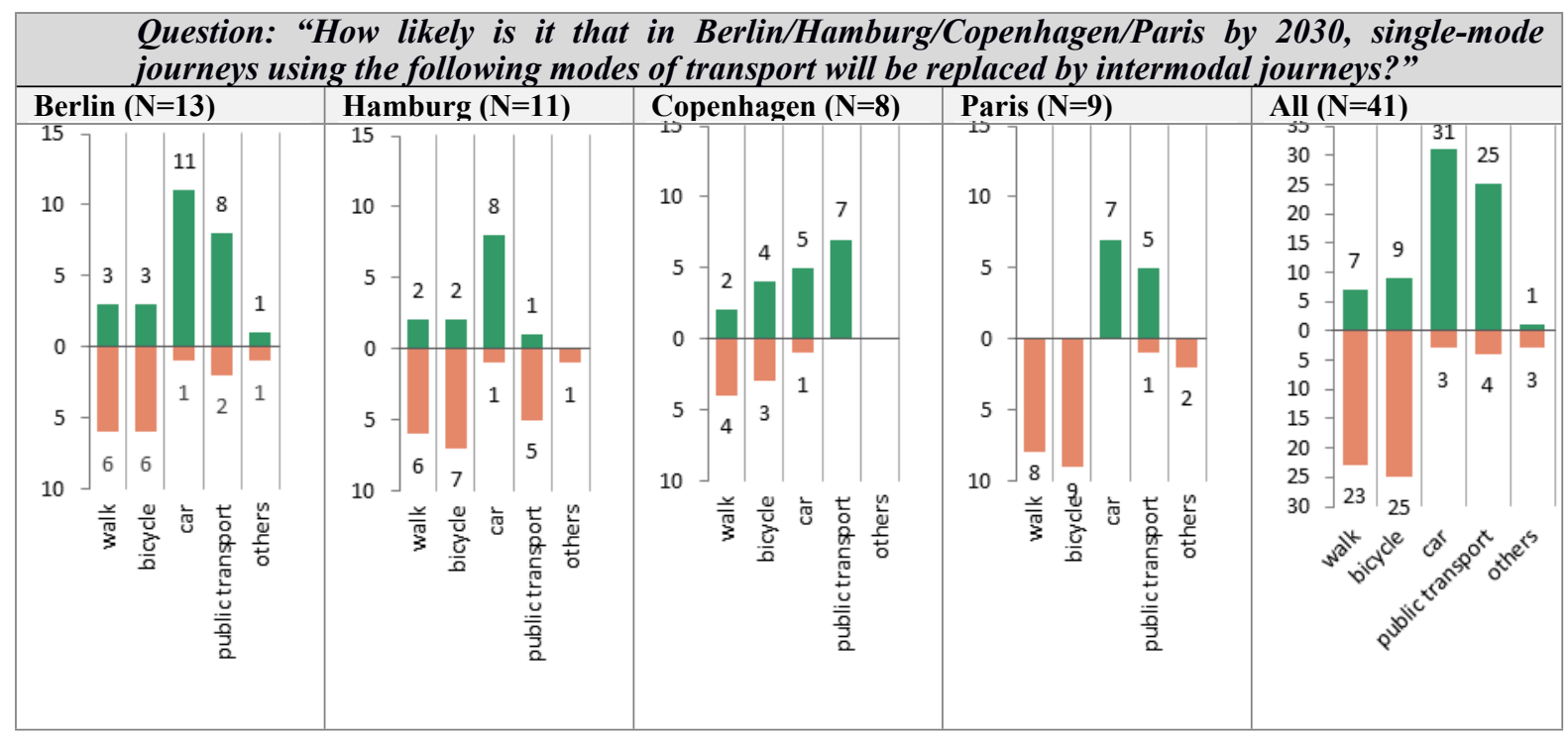


Fig 6 Modal shift arising from the promotion of intermodality, round 2 (missing values of $\mathrm{n}$ due to neutral values missing in iceberg diagrams ${ }^{5}$ : see Section 3.2.1)

On the subject of the future expected development of intermodality, we now take a more detailed approach to the description of intermodal chains. With the exception of Paris, most experts agree that an increase in cycling and public transport between now and 2030 is likely (see Figure 7). This result should be interpreted against the background that in Paris only $2 \%$ of all trips are made by bike (in 2010), and the combination of cycling and public transport is currently almost non-existent (at $0.1 \%$ of trips) (see Figures 3 and 4 ).

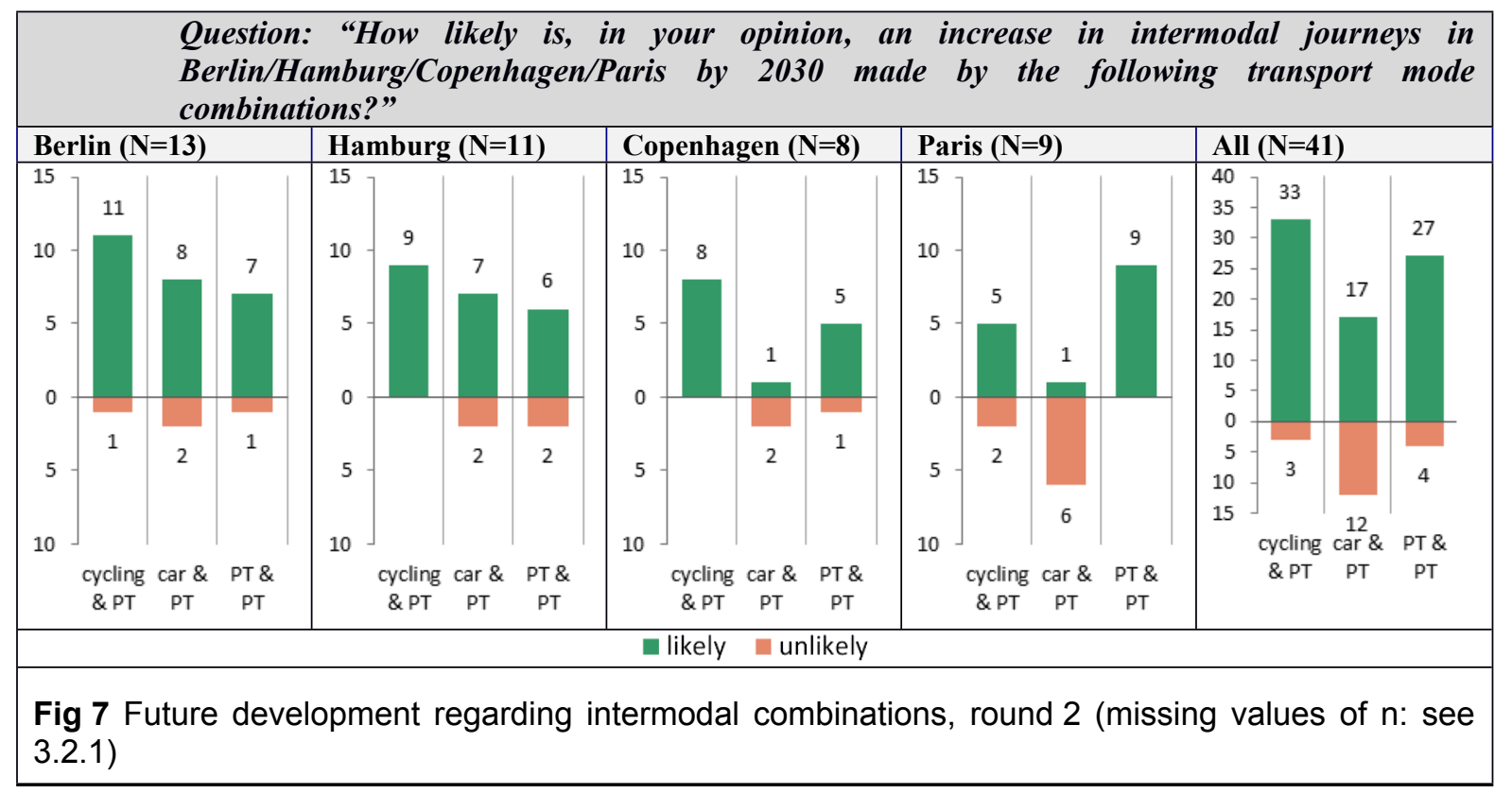

Regarding the combinations car and public transport and public transport and public transport, the experts' opinions differ from city to city. However, similarities between Hamburg and Berlin can be identified, as experts from both cities tend to find an increase in car and public transport fairly likely. In contrast, most Paris' experts think that this combination will become less popular whereas Copenhagen's experts are somewhat undecided (five of the eight chose “neither").

Across all the case study cities, only a few experts consider a growth of the combination of public transport and public transport unlikely. About half of the experts in both German cities expect an increase in this combination, two thirds in Copenhagen think it is likely, and, remarkably, all experts from Paris expect this number to grow. All case study cities plan to extend their PT system and to improve their interchange points.

Not all transport modes that will be available in the future are known of today; new modes - or modes which are hardly used today - could significantly grow in coming years, and contribute to intermodal chains. Even today, transport modes are being further developed and concepts such as car- and bike sharing are gaining importance and acceptance

${ }^{5}$ The number of neutral values for a given mode and city can be deduced by noting the difference between the value of $\mathrm{n}$ for the city and the number responses shown for that mode. For example, 'walk' in Berlin yielded $(13-(3+6))=4$ neutral responses, as did 'bicycle' also. 
on a global scale. All of the case study cities analysed are already providing a wide range of sharing concepts to complement the local transport system. But how likely do experts consider these new modes of transport to be involved in intermodal trips, and which means of transport do they regard as suitable for intermodal trips? We addressed this interesting question by asking the experts how likely they thought it that new modes of transport would be part of intermodal transport chains in the future, and which new modes of transport would combine with other modes to form intermodal journeys in 2030 (see Figure 8).

The findings indicate that the majority of all experts expect an increase in intermodal trips which include a new means of transport for most of the cities. The exception is Copenhagen, which shows a tendency towards unlikeliness of this occurring, in the experts' view. Only one of eight experts thinks that the use of these offers is likely in this city for intermodal trips. Copenhagen has the smallest spatial footprint of all case study cities - this might mean that there will be less need to combine new modes of transport with other vehicles than is the case elsewhere.

Concerning the question as to which new modes of transport will be used on intermodal trips in future, 'bike sharing' is the highest-rated answer. Again, Copenhagen is an exception, with none of the experts naming 'bike sharing'. Further modes of transport named are 'car sharing', 'ride hailing (particularly in Berlin), 'autonomous vehicles as shuttles for PT' and 'micromobility'.

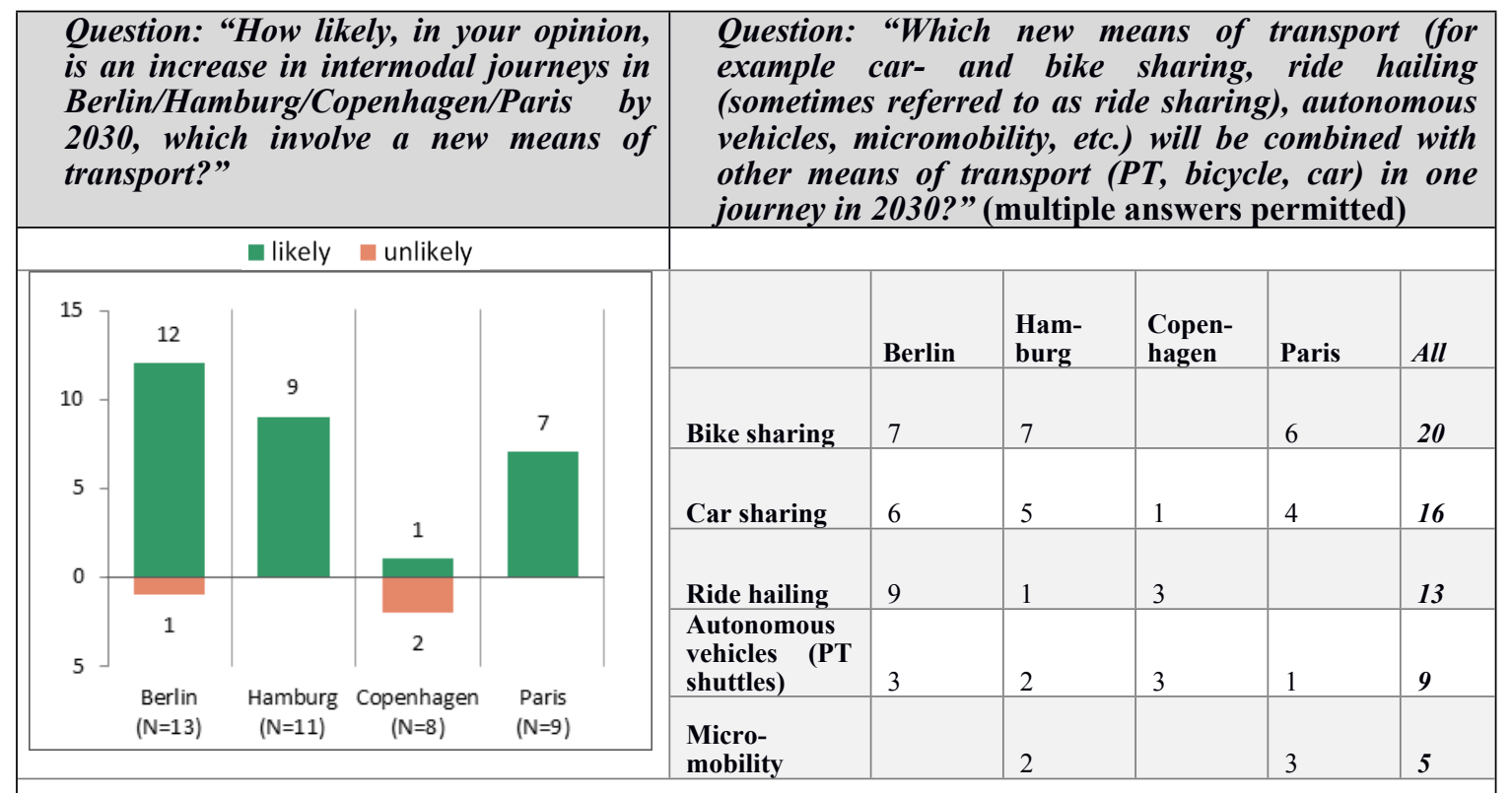

Fig 8 New intermodal combinations, round 2 (missing values of $n$ : see 3.2.1)

\subsubsection{Future relevance and potential for transport planning}

We asked survey participants: "How do you assess the future relevance of intermodality in transport planning?" Figure 9 graphs the results and shows that the clear majority of panellists in each case study city believe that intermodality will be either very relevant or relevant in future transport planning. Similarities in the results can be identified between the German cities Berlin and Hamburg, as some experts consider intermodality to be of less relevance. In contrast, none of the experts in Copenhagen or Paris contemplate intermodality as less relevant. In fact, about $85 \%$ assessed it as either very relevant or relevant. 


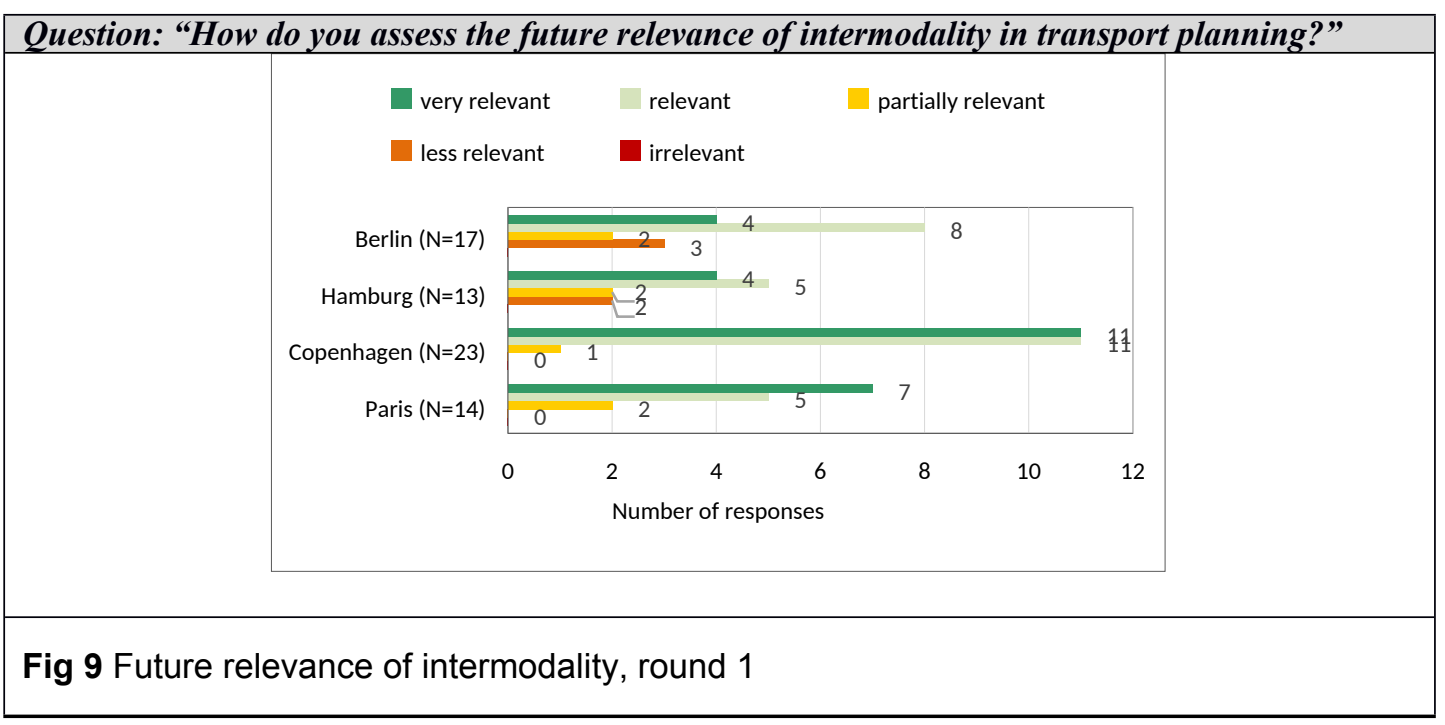

To gain further insights into the potential of intermodality to contribute to sustainable transport planning, a selection of objectives was validated by the experts. First, panellists were asked to assess two statements concerning the promotion of 'green' modes of transport (see Figure 10a), as well as an attractive cityscape / improved quality of life (see Figure 10b).

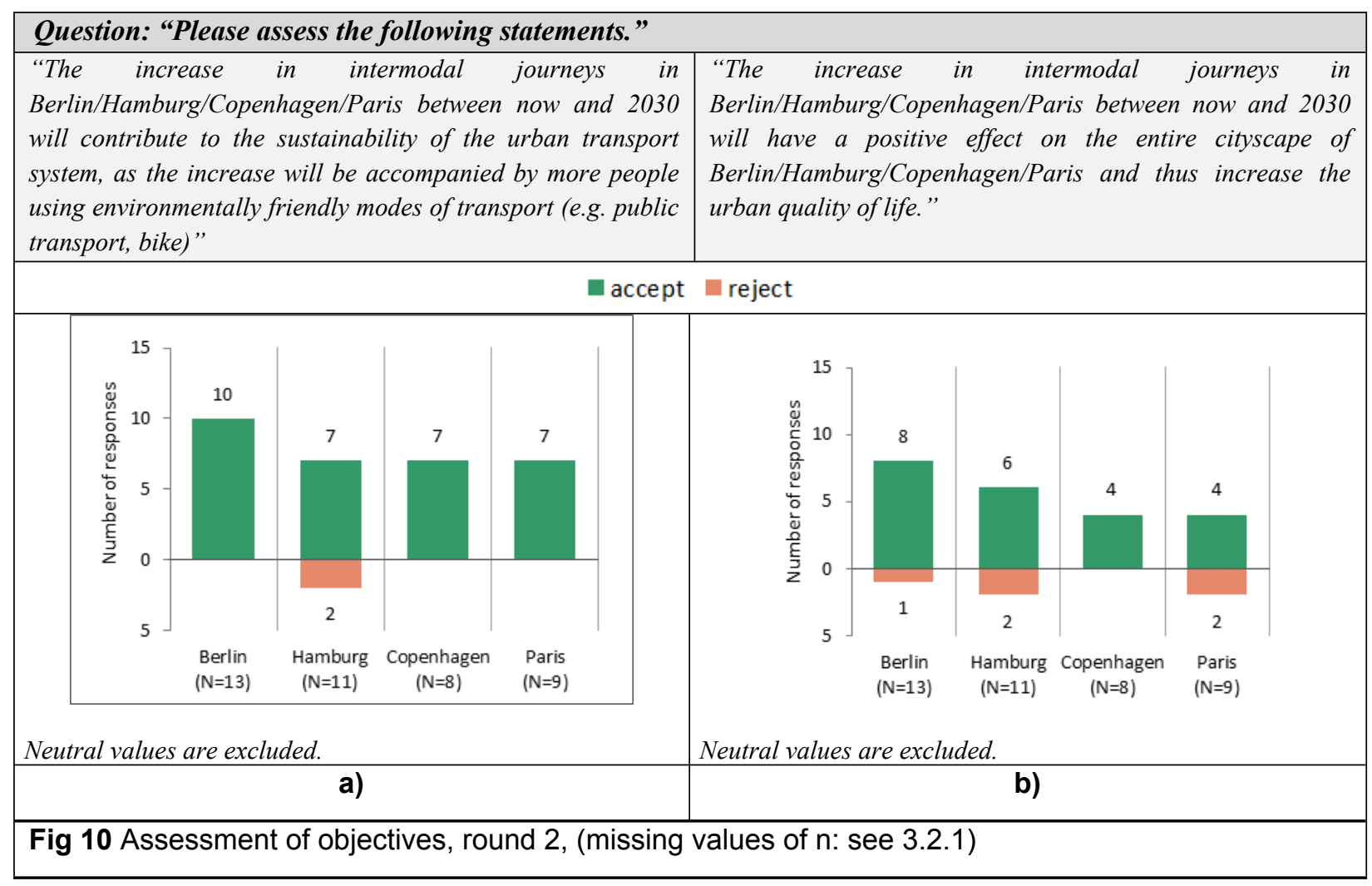

Figure 10 shows the results, including the number of experts who accept and the number who reject each statement. Regarding the first statement, about $75 \%$ of all experts (31 out of 41 ) believe it is likely that the use of 'green' modes of transport will intensify as a result of an increase in intermodal trips. The evaluation of the second statement shows that 
about half of the experts in each city expect intermodality to have a positive impact on the cityscape, and consequently on the urban quality of life.

The results show that intermodality is seen as having a positive effect on sustainable mobility, but is perhaps not so strongly linked to the quality of life in cities.

\subsubsection{Influencing factors (and user motives)}

Intermodality is affected by various external factors. We asked the panellists (see Figure 11) to assess a number of (a) social trends and (b) elements of the mobility supply in terms of their impact on intermodality. As the outcome was similar throughout all cities, the results were aggregated.

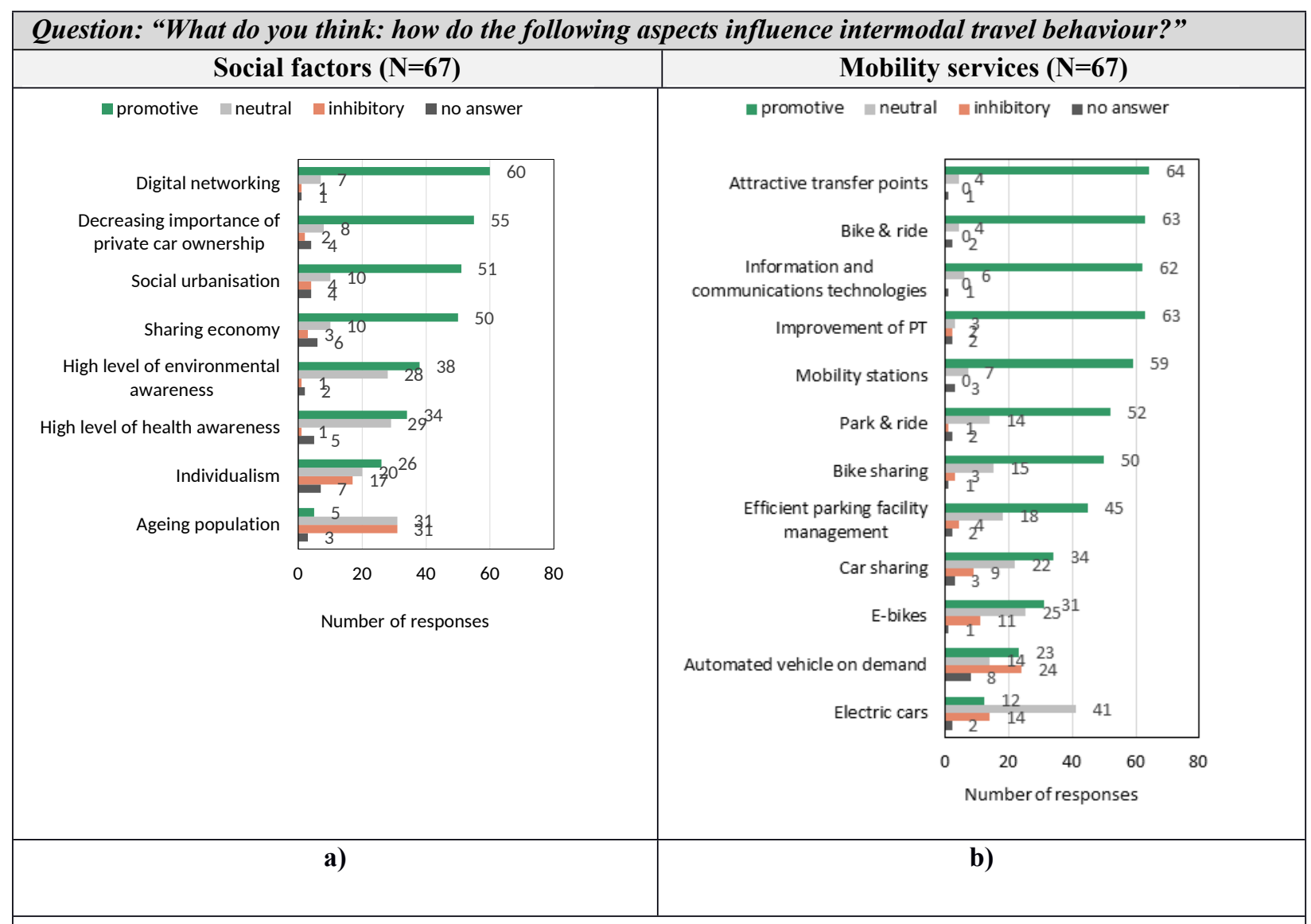

Fig 11 Factors influencing intermodality, round 1

Regarding social factors, the trends towards Digital networking, Decreasing importance of private car ownership and Social urbanisation (closely followed by Sharing economy) were, in particular, identified as factors promoting intermodality. The results for the impact of the various mobility services on intermodality show that most experts rated Attractive transfer points, Bike \& ride, Information and communications technologies and Improvement of public transport as clearly being factors which promote intermodality. This emphasises the importance of linking elements 
together for the success of intermodality - this applies both on the infrastructural level (e.g. Attractive transfer points) and on an informational level (e.g. Information and communications technology). The strongest inhibitory factor is considered to be the increasing proportion of older people. With regard to the impact of individualism and automated vehicle on demand expert opinions are more diverse.

To gain a deeper understanding of individual user preferences in the context of intermodal travelling, panellists from all case study cities were asked to assess a selection of motives that might, on the one hand, encourage intermodal travel behaviour, and also motives that might actually work against it. Motives were rated by their impact on intermodality. Figure 12 shows the findings for all cities. As these questions were not city-specific, the results were aggregated.

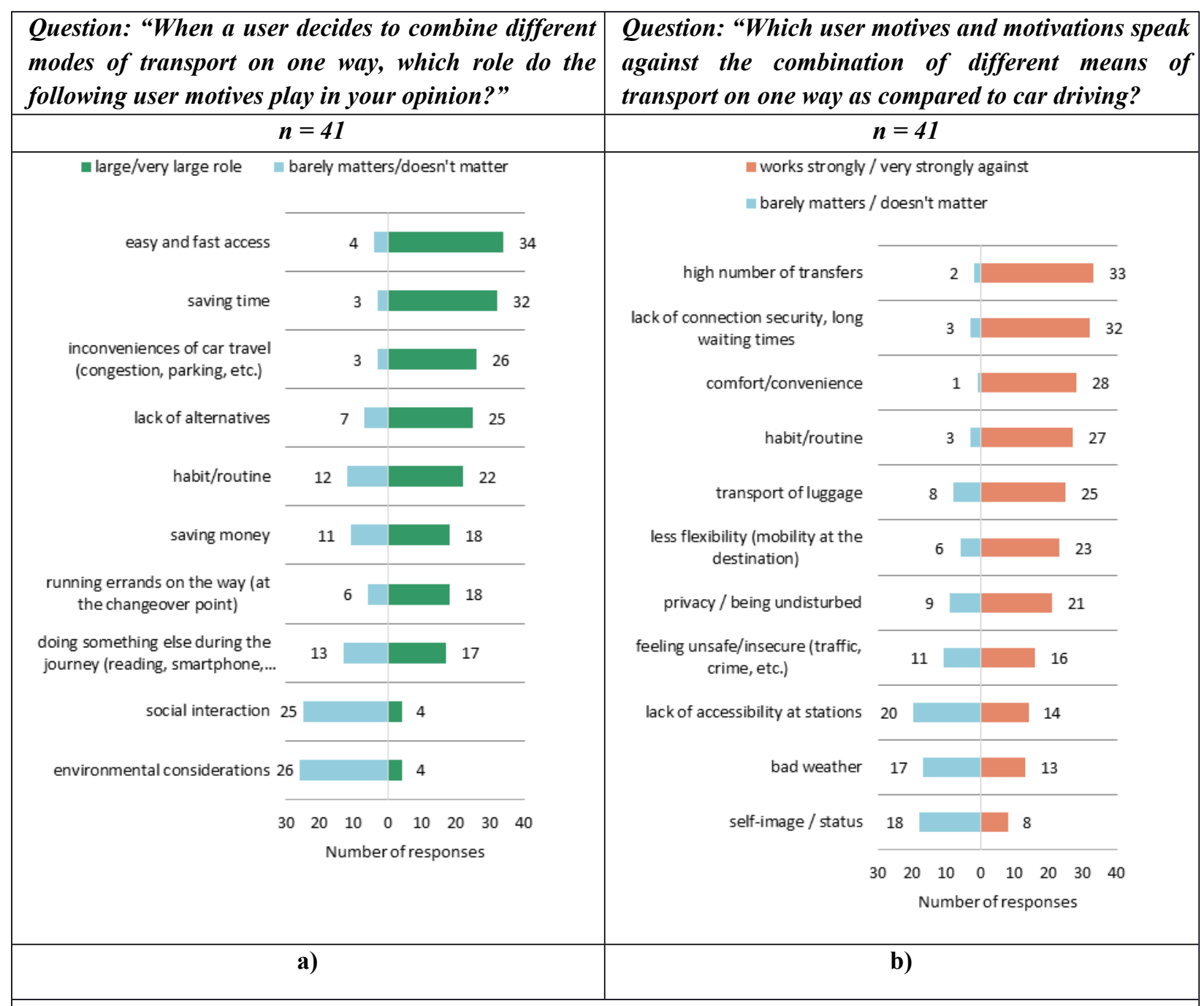

Fig 12 Motives that encourage intermodal travelling (a) and motives that discourage it (b), round 2 (missing values of $n$ : see 3.2.1)

Figure 12 a) shows the motives that are regarded as encouraging intermodal travel behaviour, b) those that discourage it. As the results show, experts believe that intermodal travel behaviour is fostered by "easy and fast access" (34/41; $83 \%)$, when people expect to "save time" (32/41, 78\%) or because of "inconveniences of car travel (congestion, 
parking, etc.)" (26/41, 63\%), but also due to "lack of alternatives” (25/41, 61\%). Other important factors include "saving costs" (18/41, 44\%), "running errands on the way" (also 18/41, 44\%), and "doing something else during the journey" (17/41, 41\%), while, interestingly “social participation / contact” and "environmental protection" (both 4/41, $10 \%$ ) do not seem to positively affect intermodal travel behaviour (25 and 26 out of 41 respectively answered "barely matters / doesn't matter").

Figure $12 \mathrm{~b}$ ) shows the motives that are seen as hindering intermodal travel behaviour. The experts expect that a "high number of transfers" (33/41, 80\%) and "lack of connection security / long waiting times" (32/41, 78\%) discourage or strongly discourage intermodal travel behaviour.

In addition to these mobility service-related aspects, functional and affective motives were evaluated.

"Comfort/convenience" (28/41, 68\%) and "habit/routine" (27/41, 66\%) were, in particular, named as discouraging or strongly discouraging intermodal travel behaviour. These responses may seem to contradict the findings on the 'encourage' side at first sight, as "habit/ routine" has also been put forward as affecting intermodality in a positive way and "inconveniences of car travel" contradicts "comfort/convenience". However, this may simply reflect the differences in travel behaviour of people with differing preferences, which leads to different reactions when facing similar transport situations/choices.

According to more than half of the panellists, further aspects that might discourage intermodal trips are the "transport of luggage" (25/41, 61\%), "less flexibility” (23/41, 56\%) and the wish for "privacy / being undisturbed" (21/41, 51\%). The aspects "lack of accessibility at stations" (14/41, 34\%), "bad weather" (13/41, 32\%) and the symbolic motive of "self-image / status" (8/41, 20\%) are ambiguous: almost half of all panellists think that the first two motives do not or only barely discourage intermodality, but at the same time one third think that these points discourage or strongly discourage intermodal traffic. Only few experts think that the motive of "self-image" discourages intermodal travel behaviour.

It must be borne in mind that the preferences of users can differ widely, depending on sociodemographic aspects, their place of residence, and the local transport service. Here, more so than with other aspects covered in the survey, it is likely that experts are also drawing on their personal experiences and motives as travellers, in addition to their scientific knowledge and professional experience. However, the high homogeneity of results among the experts across cities does support the validity of the results.

\section{Discussion}

The aim of this paper has been to analyse the success factors and framework conditions of intermodality in a European context. The cities of Berlin, Hamburg, Copenhagen and Paris were chosen as case studies in a two-wave survey. Although the cities differ with regard to the current level of intermodality and the role of different transport modes used in them, we found a high level of consensus among the experts from the four cities in the evaluation of the role of different factors affecting intermodality. Generally, experts regarded intermodality as relevant to future transport planning, and expected an increase in intermodal trips of around 15 percentage points by 2020 . In addition, most expected that this trend will have a positive impact on sustainability. 
While we would have expected that 'transit metropolises' (Cervero, 1998, Klinger et al., 2013) see the most potential in the combination of PT with other modes such as the car or the bicycle, this could only be confirmed for Berlin and Hamburg. Actually, all the cities' experts except those from Paris see the most potential in the combination of bike with PT. Paris, by contrast, rates as most promising the potential of the combination of different PT services with each other more highly than the other three cities. While both German cities also see high potential for the combination of the car with PT, this is neither the case for Paris nor for Copenhagen.

As for the 'cycling city' of Copenhagen, we expected that more potential would have been seen for non-bicycle related combinations and services in the future, as existing cycling levels are already very high. However this could not be confirmed, because experts in Copenhagen still see a high potential for the intermodal combination of PT with the bike. However, while bike sharing is expected to play a relevant role in intermodal travel in the other three cities, this is not the case for Copenhagen - and the same is true for car sharing. One explanation for this might be that both services are already used extensively, but mainly for single-mode trips, because of the shorter distances that are covered within Copenhagen, meaning that the combination of these shared-mobility services with other modes is required to a lesser extent there than elsewhere.

Concerning the factors that facilitate or hamper intermodal transport, most new mobility forms and services were expected to have the effect of promoting intermodal trips - this applied particularly to attractive transfer points and mobility stations, bike \& ride services, information and communication technologies, and general improvements to PT services. Responses related to the motives that encourage or discourage intermodal travelling (Figure 12) especially emphasise the very great relevance of the attractiveness of interchange points and provision of a high-performance public transport system to the promotion of intermodality. By contrast, the role of automated vehicles on demand was considered equally to have a positive and a negative impact, reflecting the fact that such vehicles may indeed foster point-to-point connections, but may also end up becoming part of integrated transport systems, serving primarily as feeder systems. This might depend on the more general consequences which experts expect to result from the rise of such services: will they lead to less car ownership and therefore more (other) intermodal trips, or will they lead to a general increase in car trips, as a result of giving more people access to a car? Recent studies indicate that the advent of the self-driving car is likely to result in an increase in travel demand (Harb et al., 2018, Nielsen \& Haustein, 2018). This points to a need for regulation in this area, to make sure that the future technological developments actually improve mobility and local conditions in cities, instead of increasing car use, even if that increase is decoupled from ownership.

Regarding the role of societal changes and trends, most experts evaluated digitalisation as a factor that facilitates intermodality, followed by the decreasing importance of private car ownership, social urbanisation and the sharing economy (i.e. shared mobility in our case). While experts clearly regarded the ageing population as a factor inhibiting intermodality, they were more divided when it came to the role played by individualism. While the negative expectations with regard to the effect of an ageing population may be realistic, this also points to an urgent need to make intermodal transport services more attractive for older people, so that these services can play a larger role in fulfilling older people's mobility needs in the future. Attractive transfer points with good lighting conditions, equipped with a sufficient number of benches and toilets, are surely among the aspects that make intermodality less off-putting for older people (Risser et al., 2010). Because digitalisation is identified as a key factor in intermodal transport, it remains vital that future digital solutions are designed in a highly user-friendly way in order to ensure that they do not 
attract only tech-savvy people and exclude others. With respect to individual motives, most experts regard the functional aspects of the level of service as important - these include easy and fast access, a low number of transfers, convenience and time gains. By contrast social and symbolic motives, including environmental considerations, are not considered to be motives relevant in promoting intermodal trips. While symbolic and affective evaluations of transport modes are relevant for mode choice in general, intermodality by definition includes different kinds of modes, which makes an evaluation of these aspects across modes difficult; it might be more relevant to estimate them for specific combinations of transport modes (e.g. bike and public transport vs car and public transport) in future studies.

In conclusion, we can identify an adequate transport system, as well as supportive policy measures, as fundamental requirements for the encouragement of intermodal travel behaviour. From our research, we deduce that the following factors are fundamental for supporting integrated intermodal transport systems:

- better connections between, and integration of, different transport modes to allow easy access to them and combination of them; this should include both infrastructural and informational measures (for example: bikeand-ride in urban areas, park-and-ride in the suburbs, mobility stations that also address the needs of older people, integrative mobility apps, educational initiatives);

- an overall strengthening of PT systems to decrease waiting times, allow for fast interchanges, and deliver an overall improved user experience;

- integration of new mobility concepts and technologies into the existing transport system (bike sharing, car sharing and vehicle-on-demand, all as services complementary to PT); and

- improving the conditions for environmental friendly modes of transport, meanwhile regulating car-based services (including the automated vehicles on demand of the future).

The measures should be customised and applied individually, in a way that is appropriate to the existing travel system, urban structure and travel demand.

\section{Limitations and future work}

While this study allowed for initial conclusions and policy recommendations in relation to intermodality in European cities, we can see several ways of further improving the quality of the work. One limitation of this study is the selection of the case study cities. A more comprehensive set of cities would be needed if a more representative appraisal of the role of intermodality is sought. Furthermore, the selection was based not only on theoretical criteria, but also on practical considerations, including the availability of data for comparison. A different approach to selection could have resulted in a choice of cities with a more systematic variation of infrastructural and mode-share structure, and might have enabled stronger conclusions to be drawn with regard to the variability of European urban situations. Studying a broader base of cities with a comparable method would, in any case, provide interesting results.

Other limitations relate to the travel surveys that we used: First, differing survey approaches, and second different survey years. As a result of the different survey approaches, the inter-city results are not perfectly comparable: for example, the survey days of weekdays differ, and some surveys classify the PT modes into rail-based and road-based modes, while others do not. We tried to harmonize this during the travel survey analysis, but this had limitations. However, as the respondents mainly had to answer questions related to one city, the differing survey approaches and the 
different years likely only marginally affected their responses. Another limitation is the relative maturity of some of the travel surveys. As a result of this, in some cities the actual situation may have been different from what the survey indicated. However, we compared the results for Berlin (2013 vs. 2008) and discovered only slight differences, for instance the difference was max. plus or minus 1 percent on the level of modal split. We ex-ante choose a Delphi survey as the methodological approach because of its forecasting and opinion-forming function. Owing to the homogeneity of the results after the first round, we did not find it relevant to further increase the level of agreement among the experts. Instead we asked the experts for the evaluation of additional aspects, which is a deviation from the standard Delphi method. Lastly, out attempts to balance the panellist's field of employment in Paris did not succeed, and this may at least partially have influenced the results.

Although the present potential and the future development of intermodal transport behaviour is highly dependent on the city in question and its current mobility culture, some recommendations could be derived as applying to all four case study cities, and we assume that these recommended measures can also be applied to other cities with similar characteristics. Nevertheless, further studies should examine their effectiveness in different mobility cultures.

\section{List of Abbreviations}

BVG Berliner Verkehrsbetriebe

EGT Enquete Global Transport

EPOMM European Platform on Mobility Management

MiD Mobilität in Deutschland

PT Public Transport

SrV System repräsentativer Verkehrserhebungen

VBB Verkehrsverbund Berlin-Brandenburg

\section{References}

Anable, J. and Gatersleben, B. (2005) "All work and no play? The role of instrumental and affective factors in work and leisure journeys by different travel modes." Transportation Research Part A: Policy and Practice 39 (2), pp. 163-181.

Bauman, Z. (2000) „Liquid Modernity“ Vol. 9., Cambridge: Polity Press.

Becker, H., Ciari, F., and Axhausen, K. W. (2017). “Comparing car-sharing schemes in Switzerland: User groups and usage patterns.” Transportation Research Part A: Policy and Practice, 97, pp. 17-29.

Becker, H., Ciari, F., and Axhausen, K. W. (2018). "Measuring the car ownership impact of free-floating car-sharing-A case study in Basel, Switzerland. "Transportation Research Part D: Transport and Environment, 65, pp. 51-62. 
Brög, W., Barta F. and Erl, E. (2005) "Societal megatrends: like it or not, the framework is set." 56th UITP World Congress.

Canzler, W. and Knie, A. (2016). "Mobility in the age of digital modernity: why the private car is losing its significance, intermodal transport is winning and why digitalisation is the key". Applied Mobilities 1 (1): pp. $56 \square 67$.

Cervero, R. (1998). “The transit metropolis: a global inquiry.” Island press.

Chlond, B. (2013) "Multimodalität und Intermodalität," Nicht weniger unterwegs, sondern intelligenter? Neue Mobilitätskonzepte., Berlin, 2013, pp. 271-293.

Chlond, B. and Ottmann, P. (2007) "Das Mobilitätsverhalten Alleinerziehender und ihre Aktivitäten außer Haus.," in Im Brennpunkt: Städtische Mobilität und soziale Ungleichheit., Berlin, Deutsches Institut für Urbanistik, pp. 49-61.

Chlond, B., and Manz, W. (2000). "INVERMO-Das Mobilitätspanel für den Fernverkehr.“ Arbeitsbericht IfV-Report Nr. 00-9, Institut für Verkehrswesen, Universität Karlsruhe.

Conesa A. and L'Hostis, A. (2013) "Defining Intermodal Accessibility," Geographical Information and Urban Transport Systems, pp. 53-81

Coughlin, J. F. (2009) "Longevity, Lifestyle, and Anticipating the New Demands of Aging on the Transportation System." Public Works Management \& Policy 13 (4), pp. 301-311

Dacko, Scott G., and Carolin Spalteholz. (2014) "Upgrading the City: Enabling Intermodal Travel Behaviour." Technological Forecasting and Social Change 89 (novembre), pp. $222 \square 35$.

Dalkey, N. C. (1969) “The Delphi method: An experimental study of group opinion.” No. RM-5888-PR. RAND CORP SANTA MONICA CALIF.

Delbosc, A. and Currie, G. (2013) "Courses of youth licensing decline: a synthesis of evidence," Transport Reviews 33, pp. 271-290.

Dijsktra, L., Garcilazo E. and McCann, P. (2013) "The Economic Performance of European Cities and City Regions: Myths and Realities." European Planning Studies 21 (3), pp. 334-354

Christiansen, H. and Warnecke, M-L. (2018). The Danish National Travel Survey - declaration of variables TU 2006-17, version 1. Dataset, DTU Management

EPOMM (n.d.), "EPOMM database," Mobiel 21, [Online]. Available: http://www.epomm.eu/tems/.

Euromonitor (2013) "Downsizing Globally: The Impact of Changing Household Structure on Global Consumer Markets." [Online]. Available: https://www.euromonitor.com/downsizing-globally-the-impact- 
of-changing-household-structure-on-global-consumer-markets/report

European Commission (2011) "European Commission. 2011. Impact assessment Accompanying document to the White Paper: Roadmap to a Single European Transport Area - Towards a competitive and resource efficient transport system."

Eurostat (2009) "Reconciliation between work, private and family life in the European Union." Statistical Books. Eurostat."

Etzkowitz, H., \& Leydesdorff, L. (1995). The Triple Helix--University-industry-government relations: A laboratory for knowledge based economic development. EASST review, 14(1), 14-19.

Flyvbjerg, B. (2006) "Five Misunderstandings about Case Study Research." Qualitative Inquiry, Volume 12 Number 2, pp. 219-245.

Fornells, A. and Arrue, A. (2014) "COMPANION D2.2 Current state of EU legislation" Edinburgh: European Commission.

Gebhardt, L., Krajzewicz, D., Oostendorp, R., Goletz, M., Greger, K., Klötzke, M., Wagner, P. and Heinrichs, D. (2016). "Intermodal urban mobility: users, uses, and use cases." Transportation Research Procedia, Volume 14,, pp. 1183-1192.

Gerring, J. (2004) "What is a case study and what is it good for?" The American Political Science Review (Vol. 98, No. 2), pp. 341-354.

Goletz, M., Feige, I. and Heinrichs, D. (2016) "What Drives Mobility Trends: Results from Case Studies in Paris, Santiago de Chile, Singapore and Vienna.," Transportation Research Procedia 13, pp. 49-60.

Goodall, W., Fishman, T., Dixon, S., and Perricos, C "Transport in the Digital Age, Disruptive Trends for Smart Mobility." Deloitte, 2015.

Häder, M. (2014) “Delphi-Befragungen. Ein Arbeitsbuch.” Wiesbaden.

Habibi, A., Sarafrazi, A., and Izadyar, S. (2014). "Delphi technique theoretical framework in qualitative research." The International Journal of Engineering and Science, 3(4), pp. 8-13.

Häder, M. and Häder, S. (2014) "DELPHI-Befragung." Handbuch Methoden der empirischen Sozialforschung, Wiesbaden, pp. 587-592.

Harb, M., Xiao, Y., Circella, G., Mokhtarian, P. L., \& Walker, J. L. (2018).” Projecting travelers into a world of self-driving vehicles: estimating travel behavior implications via a naturalistic experiment." Transportation, 45(6), pp. 1671-1685.

Harper, C., Mangones, S., Hendrickson, C., and Samaras, C. (2015) "Bounding the Potential Increases in 
Vehicles Miles Traveled for the Non-Driving and Elderly Populations and People with Travel-Restrictive Medical Conditions in an Automated Vehicle Environment.," Transportation Research Board 94th Annual Meeting (No. 15-1609).

Hasson, F., Keeney, S., and McKenna, H. (2000). "Research guidelines for the Delphi survey technique." Journal of advanced nursing, 32(4), pp. 1008-1015

Haustein, S. (2006) „Mobilitätsverhalten in Abhängigkeit von der partnerschaftlichen Lebensform.“ Umweltpsychologie, Vol.10, No. 2, pp. 160-182.

Haustein, S., and Siren, A. (2015). “Older people's mobility: Segments, factors, trends." Transport Reviews, 35(4), 466-487.

Heinen, E., and Chatterjee, K. (2015). „The same mode again? An exploration of mode choice variability in Great Britain using the National Travel Survey." Transportation Research Part A: Policy and Practice, 78, pp. 266-282.

Heinen, E., and Mattioli, G. (2019). "Does a high level of multimodality mean less car use? An exploration of multimodality trends in England.” Transportation, 46(4), pp. 1093-1126.

Hunecke, M., Haustein, S., Grischkat, S., and Böhler, S. (2007) "Psychological, sociodemographic, and infrastructural factors as determinants of ecological impact caused by mobility behavior." Journal of Environmental Psychology 27(4), pp. 277-292.

Jain, J. and Lyons, G. (2008) "The gift of travel time." Transport Geography 16 (2), pp. 81-89.

Jain, T., Johnson, M., \& Rose, G. (2020). Exploring the process of travel behaviour change and mobility trajectories associated with car share adoption. Travel Behaviour and Society, 18, 117-131.

Jittrapirom, P., Caiati, V., Feneri, A. M., Ebrahimigharehbaghi, S., Alonso González, M. J., and Narayan, J. (2017) "Mobility as a Service: A Critical Review of Definitions, Assessments of Schemes, and Key Challenges." Urban Planning 2(2), pp. 13-25.

Jones, W. B., Cassady, C. R., and Bowden Jr, R. O. (2000) "Developing a standard definition of intermodal transportation," Transportation Law Journal (27), pp. 345-352.

Kirchhoff, S., Kuhnt, S., Lipp, P., and Schlawin, S. (2010). Der Fragebogen. Wiesbaden: VS Verlag für Sozialwissenschaften.

Klinger, T., Kenworthy, J. R., and Lanzendorf, M. (2013) "Dimensions of urban mobility cultures - a comparison of German cities," Journal of Transport Geography, 31, pp. 18-29.

Kopp, J., Gerike, R., and Axhausen, K. W. (2015) "Do sharing people behave differently? An empirical evaluation of the distinctive mobility patterns of free-floating car-sharing members.," Transportation, 
42(3), pp. 449-469.

Kuhnimhof, T. Zumkeller, D. and Chlond, B. (2013) "Who Made Peak Car, and How? A Breakdown of Trends over Four Decades in Four Countries," Transport Reviews, 33(3), 325-342.

Kuhnimhof, T., Armoogum, J., Buehler, R., Dargay, J., Denstadli, J. M., and Yamamoto, T. (2012) „Men shape a downward trend in car use among young adults—evidence from six industrialized countries." Transport Reviews, 32(6), 761-779.

Kuhnimhof, T., Chlond, B., \& Von Der Ruhren, S. (2006). „Users of transport modes and multimodal travel behavior: Steps toward understanding travelers' options and choices." Transportation research record, 1985(1), 40-48.

Kunert, U. (1994) "Singles: Zahlreich und mobil. Zum Mobilitätsverhalten alleinlebender Personen.," in $S$. Gräbe (Ed.), Lebensform Einpersonenhaushalt: Herausforderungen an Wirtschaft, Gesellschaft und Politik, Frankfurt a.M., Campus, pp. 133-158.

L’Hostis A. et al. (2016) "MOBILITY4EU - D2.1 - Societal needs and requirements for future transportation and mobility as well as opportunities and challenges of current solutions ," Research Report. IFSTTAR - Institut Français des Sciences et Technologies des Transports, de l'Aménagement et des Réseaux.

Laihonen, A. (2003) "Trends in households in the European Union: 1995-2025 ." Statistics in focus. Eurostat. [Online]. Available: http://ec.europa.eu/eurostat/en/web/products-statistics-in-focus/-/KS-SF-09094.

Lanzendorf, M. Gather, M., Wall, G. T., Hounsell, N. B., Scheiner J. and A. M. (2005) "Special issue: Institutional, economic and demographic transition and its impact on the transport system." EJTIR 5 (3), pp. 135-138.

Le Vine, S. and Jones, P. (2012) "On the move. Making sense of car and train travel trends in Britain.," RAC Foundation, London. [Online]. Available:

http://www.racfoundation.org/assets/rac_foundation/content/downloadables/on_the_move-

le_vine_\&_jones-dec2012.pdf.

Linstone, H. A. and Turoff, M. (1975) “The Delphi Method. Techniques and apllications.” Reading, Massachusetts, Addison-Wesley Publishing Company.

MiD (2008)"Mobilität in Deutschland - MiD 2008." Household Travel Survey, Hamburg Region, Amt für Verkehr und Straßenwesen der Behörde für Wirtschaft, Verkehr und Innovation (BMVI), Hamburg.

Mishra, G. S., Clewlow, R. R., Mokhtarian, P. L. and Widaman, K. F. (2015). "The effect of carsharing on vehicle holdings and travel behavior: A propensity score and causal mediation analysis of the San 
Francisco Bay Area.” Research in Transportation Economics, 52, pp. 46-55.

Mishra, G. S., Mokhtarian, P. L., Clewlow, R. R. \& Widaman, K. F. (2019). Addressing the joint occurrence of self-selection and simultaneity biases in the estimation of program effects based on crosssectional observational surveys: case study of travel behavior effects in carsharing. Transportation, 46(1), 95-123.

Nielsen, T. A. S., \& Haustein, S. (2018) "On sceptics and enthusiasts: What are the expectations towards self-driving cars?.” Transport policy, 66, pp. 49-55.

Nobis, C. (2007) “Multimodality: facets and causes of sustainable mobility behavior." Transportation Research Record, 2010(1), pp. 35-44.

OECD (2012) "Redefining 'Urban’ A New Way to Measure Metropolitan Areas: A New Way to Measure Metropolitan Areas." OECD Publishing

Reimer, B. (2014) "Driver assistance systems and the transition to automated vehicles: A path to increase older adult safety and mobility? " Public Policy \& Aging Report, 24(1), pp. 27-31.

Risser, R. Haindl, G. and Ståhl, A. (2010) "Barriers to senior citizens’ outdoor mobility in Europe." European Journal of Ageing, 7(2), pp. 69-80.

Shaheen, S. (2018) "Overview of Shared Mobility." ITS Berkeley Policy Briefs, 2018(01), Berkeley.

Siren, A. and \& Haustein, S. (2016) "How do baby boomers' mobility patterns change with retirement?" Ageing \& Society 36(5), pp. 988-1007.

Siren, A. and Haustein, S. (2013) " Baby boomers' mobility patterns and preferences: What are the implications for future transport?." Transport Policy 29, pp. 136-144.

SrV (2013) "Mobility in Cities" - SrV 2013.", sample Berlin, TU Dresden, Lehrstuhl für Verkehrs- und Infrastrukturplanung im Auftrag der Senatsverwaltung für Stadtentwicklung und Umwelt Berlin, Abteilung Verkehr., 2013.

Steg, L. (2005) "Car use: lust and must. Instrumental, symbolic and affective motives for car use." Transportation Research Part A 39, pp. 147-162, 2005.

STIF/DRIEA (2010) "Enquêtes Globales Transport" Household Travel Survey, Paris.

Stopka, U., Pessier, R., and Fischer, K. (2015) "User Requirements for Intermodal Mobility Applications and Acceptance of Operating Concepts." Human-Computer Interaction: Design and Evaluation. HCI 2015. Lecture Notes in Computer Science, vol 9169., pp. 415-425.

United Nations (2014) "United Nations. 2014. World urbanization prospects: The 2014 revision." 
Vorgrimler, D. and Wübben, D. (2003) "Die Delphi-Methode und ihre Eignung als Prognoseinstrument." Wirtschaft und Statistik 8/2003, pp. 763-774.

Vuchic, V. R. (2017) “Urban Transit: Operations, Planning, and Economics.” John Wiley \& Sons. 


\section{Authors' contributions}

MG was responsible for the overall study design, the selection of case study cities (2.1), the travel survey comparison (2.2), the expert survey design (2.3.3, jointly with $\mathrm{CW}$ ), the first draft and the final preparation of the manuscript; the findings of the expert survey (3.2) and the panel recruitment in Berlin and Hamburg. SH was responsible for the section about factors of intermodality (1.2), travel survey analysis for Copenhagen (2.2), developing and contextualizing the expert survey and panel recruitment in Copenhagen (2.3.), and contributed to the findings of the expert survey (3.2). CW was responsible for the methodology (2.3.1) of the expert survey and the survey outline (2.3.3), distribution of the survey in Berlin and Hamburg, discussion intermodality in the case study cities (3.1), analyzing the survey results (3.2), and setting up the online survey platform. AH was responsible for the section on context (1.1), travel survey analysis for Paris (2.2) and the panel recruitment for Paris (2.3.2). All authors contributed to the discussion (4) and the limitations (5). All authors contributed to and have read and approved the final manuscript.

Mirko Goletz (MGo), Sonja Haustein (SH), Christina Wolking (CW), Alain l'Hostis (AH) 